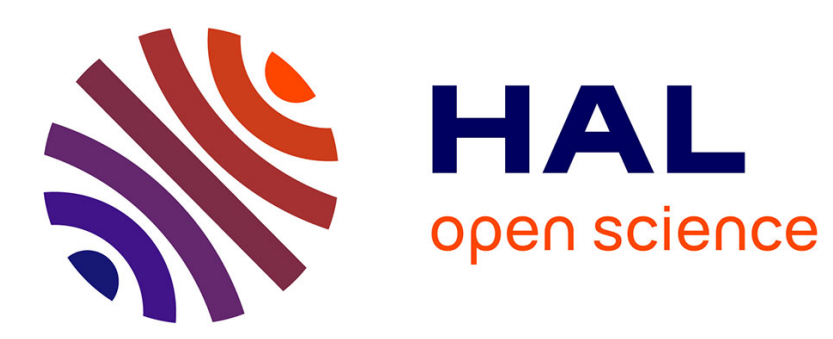

\title{
Eruption and deposition of the fisher tuff (Alaska): evidence for the evolution of pyroclastic flows.
}

\author{
James E. Gardner, Alain Burgisser, Pete Stelling
}

\section{To cite this version:}

James E. Gardner, Alain Burgisser, Pete Stelling. Eruption and deposition of the fisher tuff (Alaska): evidence for the evolution of pyroclastic flows.. Journal of Geology, 2007, 115 (4), pp.417-436. insu00160874

\section{HAL Id: insu-00160874 https://hal-insu.archives-ouvertes.fr/insu-00160874}

Submitted on 9 Jul 2007

HAL is a multi-disciplinary open access archive for the deposit and dissemination of scientific research documents, whether they are published or not. The documents may come from teaching and research institutions in France or abroad, or from public or private research centers.
L'archive ouverte pluridisciplinaire HAL, est destinée au dépôt et à la diffusion de documents scientifiques de niveau recherche, publiés ou non, émanant des établissements d'enseignement et de recherche français ou étrangers, des laboratoires publics ou privés. 


\title{
ERUPTION AND DEPOSITION OF THE FISHER TUFF (ALASKA): EVIDENCE FOR THE EVOLUTION OF PYROCLASTIC FLOWS
}

\author{
James E. Gardner,"*, Alain Burgisser ${ }^{2}$, and Pete Stelling ${ }^{3}$ \\ Alaska Volcano Observatory, Geophysical Institute \\ University of Alaska Fairbanks \\ Fairbanks, Alaska, USA
}

1) now at: Department of Geological Sciences, Jackson School of Geosciences, The University of Texas at Austin, Austin, TX 78712-0254, USA.

2) now at: Institut des Sciences de la Terre d'Orléans, CNRS - Université d'Orléans, 45071 ORLEANS Cedex 2, France

3) now at: Department of Geology, University of Alaska Anchorage, Anchorage, AK 99508, USA.

*corresponding author: office: 1-512-471-0953, fax: 1-512-471-9425; e-mail: gardner@mail.utexas.edu 


\section{ABSTRACT}

Recognition that the Fisher Tuff (Unimak Island, Alaska) was deposited on the leeside of $~ 500-700 \mathrm{~m}$ high mountain range (Tugamak Range) more than $10 \mathrm{~km}$ away from its source played a major role in defining pyroclastic flows as momentum-driven currents. We re-examined the Fisher Tuff to evaluate whether deposition from expanded turbulent clouds can better explain its depositional features. We studied the tuff at 89 sites, and sieved bulk samples from 27 of those sites. We find that the tuff consists of a complex sequence of deposits that record the evolution of the eruption from a buoyant plume $(22 \mathrm{~km})$ that deposited $\sim 0.2 \mathrm{~km}^{3}$ of dacite magma as a pyroclastic fall layer to erupting $\sim 10-100 \mathrm{~km}^{3}$ of andesitic magma as scoria-rich pyroclastic falls and flows that were mainly deposited to the north and northwest of the caldera, including those in valleys within the Tugamak Range. The distribution of the flow deposits and their welding, internal stratification, and occurrence of lithic breccia, all suggest that the pyroclastic flows were fed from a fountaining column that vented from an inclined conduit, the first time such a conduit has been recognized during a large volume caldera eruption. Pyroclastic flow deposits before and after the mountain range, and thin veneer deposits high in the Range, are best explained by a flow that was stratified into a dense undercurrent and an over-riding dilute turbulent cloud, from which deposition before the range was mainly from the undercurrent. When the flow ran into the mountain range, however, the undercurrent was blocked, but the turbulent cloud continued on. As the flow continued north, it re-stratified, forming another undercurrent. The Fisher Tuff thus records the passing of a flow that was significantly higher (800-1100 m thick) than the mountain range, and thus did not require excessive momentum. 


\section{INTRODUCTION}

Pyroclastic flows represent one of the most dangerous hazards of volcanic eruptions, causing some $27 \%$ of known deaths from eruptions (Baxter, 2000). Because it is impossible to see inside of a moving pyroclastic flow, we are left to interpret their flow dynamics from the deposits they leave behind. The study of pyroclastic flow deposits has thus been central in directing models. The Fisher Tuff, Alaska, played a pivotal role in developing such models, because it was one of the first to be recognized for its extraordinary deposition on the leeside of a large mountain range (Tugamak Range, Figure 1), 10-15 km away from Fisher volcano (Miller and Smith, 1977).

Miller and Smith (1977) argued that the Fisher Tuff was most likely deposited en masse from a relatively dense pyroclastic flow that was driven over the mountains by excessive momentum. Deposits of other pyroclastic flows were subsequently explained by similar momentum-driven deposition (e.g., Wilson and Walker, 1982). The term pyroclastic flow thus became synonymous with high particle concentration flows. Since then, physical arguments (Valentine, 1987) and numerical and analogue experiments (Dobran et al., 1993; Neri and Macedonio, 1996; Choux et al., 2004; Cordoba, 2005) have all shown that the vertical particle concentration is likely to vary greatly within a moving pyroclastic flow. Indeed, the current view is that particle concentration plays a central role in controlling the richness of flow dynamics (Dobran, 2001). In particular, high particle concentrations developing near the ground can cause a dense undercurrent to form, the motion of which can be independent of the upper parts of the flow (Fisher, 1990). Field observations of compositional changes within deposits show they are likely to form by progressive aggradation of tephra from the lower boundary of density- 
stratified flows (Branney and Kokelaar, 1992; Carrasco-Nunez and Branney, 2005). Thus, the dynamics of the boundary layer is the key to link deposit fabric to depositional mechanisms (Branney and Kokelaar, 2002). In recognition of the paradigm shift in thinking, the term "pyroclastic density current" was proposed to replace pyroclastic flows and surges. Here, we use the term pyroclastic flow to refer to a pyroclastic density current that travels along the ground, regardless of the particle concentration within it.

Deposits from pyroclastic flows can be either thick, valley-filling deposits that are generally massive and poorly sorted, or, when topography is irregular, thin veneer deposits (Druitt, 1998). Veneer deposits vary from massive to stratified, with moderately to well-sorted layers, and often occur on topographic highs (e.g., Freundt and Schminke, 1985). Massive deposits are thought to originate from highly concentrated boundary layers in which inter-particle interactions are dominant (Boudon et al., 1993). Stratified deposits probably arise from boundary layers with low particle concentration that allows particles to roll and saltate (Sohn, 1997; Burgisser and Gardner, 2006). Thus, the interaction between the flow and topography changes the characteristics of its boundary layer and the dominant depositional mechanisms.

Little is known about the development of concentration gradients within pyroclastic flows and their relationship to undercurrents. En masse deposition implied that the thickness of a pyroclastic flow was closely related to that of the deposit. With the concept of aggradation, deposit thickness instead reflects sedimentation rate and current duration. Thus, obstacles can no longer be used to infer the momentum of the parent flow, but they can be used to unravel relationships between variations of particle concentration and the boundary layer (e.g., Burgisser, 2005). We thus re-examined the Fisher Tuff in order to 
determine whether its interaction with the Tugamak Range left traces in the deposits, and to what extent those traces can be related to the development of concentration gradients within the parent flow.

The Fisher Tuff erupted $\sim 9400{ }^{14} \mathrm{C}$ years ago, forming a broad sheet of pyroclastic deposits around Fisher caldera (Fig. 2), which collapsed during the eruption (Miller and Smith, 1977; Stelling et al., 2005). The tuff can be divided into three parts, based on their dominant juvenile component and distributions: North Pumice, Scoria-rich, and South Pumice (modified from Stelling et al., 2005). The North Pumice and the South Pumice are petrologically distinct dacitic magmas, erupted from different vents (Stelling et al., 2005). The Scoria-rich deposits range in composition from basaltic andesite to andesite, with some of that range resulting from mixing between basaltic andesite and dacite of the North Pumice (Stelling et al., 2005).

\section{METHODS}

We examined the Fisher Tuff at 89 sites, all located by GPS, up to more than $50 \mathrm{~km}$ away from the caldera (Fig. 1). In addition, products erupted from Fisher volcano from the Mid-Pleistocene to Recent have been examined at another 160 sites (Stelling et al., 2005), and so we feel confident in our estimates for the distributions of the units of the Fisher Tuff. Digital elevation maps used in this study are from SRTM data. At most localities, the thickness of every layer within the tuff was measured, and any internal stratifications or variations were noted. In a few cases, we had to estimate thickness because the deposit was either too thick to measure precisely or only exposed in vertical cliffs. In many places the base of the tuff is not exposed, and so those thicknesses are 
minimums. The coarsest lithic fragments were measured in many of the layers at 27 sites, most of the time by excavating a standard volume of each layer and measuring the long axis of the five largest clasts found. Where deposits were sufficiently thick (usually $>20 \mathrm{~cm}$ ), they were subdivided and the largest lithics from each level were measured to determine the variation in size as a function of stratigraphic height. When deposits were partly or densely welded, we outlined an area on the outcrop face and measured the largest lithic clasts that were exposed.

Bulk samples were collected at several localities to determine grain-size distributions of the deposits (Table 1). Grain size is given in $\phi$ units and $\mathrm{mm}\left[\phi=-\log _{2}(\mathrm{~mm})\right]$, and the parameters used are Inman Median Size $\left(M_{\mathrm{d}}\right)$ and sorting $(\sigma)$ (Inman, 1952). Those parameters are accurate to $\pm 0.1 \phi$. All samples were wet-sieved in the laboratory to $4 \phi$ $(0.063 \mathrm{~mm})$ in $0.5 \phi$ intervals. The fraction finer than $4 \phi$ was collected in water buckets and dried. Size distributions of the fine fractions were determined to $7 \phi(0.008 \mathrm{~mm})$, using a Spectrex ILI-1000 laser particle counter. Although the counter measures sizes as small as $10 \phi(0.001 \mathrm{~mm})$ the distilled water used to dilute the sample contained impurities smaller than $7 \phi$, and so weight percents were normalized to sizes between $4.5 \phi$ and $7 \phi$. Particle counter and sieve data were combined to obtain normalized grain-size distributions. The error in weights of each size fraction is less than $0.1 \mathrm{~g}$, equivalent to an error of $\sim 0.1$ wt. $\%$. Overall, $M_{\mathrm{d}}$ varies from $-3 \phi$ to $0.5 \phi(8$ to $0.71 \mathrm{~mm})$, and $\sigma$ varies from 0.96 to 3.60 (Table 1). Following Walker (1971) and Cas and Wright (1987), we call deposits well sorted if $\sigma<2$ (very well if $\sigma<1$ ) and poorly sorted if $\sigma>2$.

Componentry of samples was obtained by manually separating and weighing a statistically significant number of the different clast types for sizes coarser than $0 \phi(1$ 
$\mathrm{mm}$ ), and by counting 500 particles per size class with a binocular microscope for the smaller sizes down to $2 \phi(0.25 \mathrm{~mm})$. We assume that the proportions of components in the $2 \phi$ size class are the same in smaller sizes. Conversions to weight fractions for pumice, lithic, glass, and crystals were done by assuming average densities of 1000, 2500,2000 , and $2500 \mathrm{~kg} \mathrm{~m}^{-3}$, respectively. To convert to weight fraction for scoria we used a density of $817( \pm 242) \mathrm{kg} \mathrm{m}^{-3}$, based on measurements of 116 scoria from sample FC-321E (Table 1). Errors on the normalized proportions are on the order of $0.1 \%$.

\section{DEPOSITS OF THE FISHER TUFF}

Stelling et al. (2005) described the overall stratigraphy of the Fisher Tuff. Here, we discuss relevant details of the stratigraphy and individual eruptive layers. We divide the Fisher Tuff into three parts: North Pumice, Scoria-rich, and South Pumice, with the Scoria-rich deposits being much more voluminous than the other two. Each part contains multiple layers, which are described below.

\section{North Pumice Deposits}

The North Pumice deposits consist mostly of a pumice-rich layer distributed along a east-northeast axis (Fig. 3). It is $~ 3-10$ meters thick on the eastern caldera wall and thins rapidly away (Fig. 4). At the eastern caldera wall the upper half of the deposit is partially welded. It also exists as a 5-cm-thick ash layer in the southern caldera wall (Fig. 5), and as one to three, 5-8-mm thick, ash layers in the Tugamak Range (Fig. 2). The pumicerich layer is well to very well sorted (Table 1), and reversely graded, with lithics 
increasing in size by $\sim 75 \%$. To the northeast there is a poorly sorted $44-\mathrm{cm}$ thick ashrich layer within the pumice-rich layer (Fig. 4).

Based on its fan-shaped distribution (Fig. 3) and well-sorted nature, we suggest that the pumice-rich layer is a pyroclastic fall layer. The poorly sorted layer in the northeast probably represents a small pyroclastic flow generated during the dominantly pyroclastic

fall event. Isopachs of the fall deposit indicate that the volume of tephra is $\sim 0.5 \mathrm{~km}^{3}$, using the methods of Pyle (1989) and Fierstein and Nathenson (1992). Our isopachs probably cover minimal areas, and hence we have likely underestimated its total volume. A tephra volume of $\sim 0.5 \mathrm{~km}^{3}$ translates to a magma volume of $\sim 0.2 \mathrm{~km}^{3}$ (dense-rock equivalent; DRE), assuming a bulk density of $1000 \mathrm{~kg} \mathrm{~m}^{-3}$.

\section{Scoria-Rich Deposits}

Deposits that are rich in scoria comprise the vast majority of the Fisher Tuff. Based on their grain-size distributions, internal structure, sorting, and geographic distribution, we divide the scoria-rich deposits into pyroclastic flow deposits or fall deposits.

\section{Scoria-Rich Pyroclastic Flow Deposits}

The pyroclastic flow deposits vary in thickness from 10's of centimeters to $>50$ meters, and are found from the northeast to the southwest in a $\sim 270^{\circ}$ arc around the caldera (Fig. 6). From the northwest to the northeast, we found $>3-10$ meters near the Bering Sea coast, within valleys of the Tugamak Range, and on the slopes of Shishaldin Volcano. Further than $\sim 26 \mathrm{~km}$ away to the northeast, however, we found only thin layers interspersed with scoria-rich pyroclastic fall deposits. To the east, west, and southwest, 
2-8 meters of pyroclastic flow deposits exist at the caldera rim, but are absent farther than $\sim 2-4 \mathrm{~km}$ from the caldera. To the south and southeast, scoria-rich pyroclastic flow deposits are absent (Fig. 6).

Scoria-rich pyroclastic flow deposits are welded to some degree near the caldera (Fig. 2). More than $50 \mathrm{~m}$ of partly to densely welded tuff is found to the north, and a few meters of welded tuff exist to the east, northwest, and west (Fig. 6). From the eastern caldera wall, welded tuff thins rapidly to only a few meters thick, and is absent $>4 \mathrm{~km}$ from the wall. The thickest welded deposits thus occur to the north of the eastern half of the caldera. At more distal sites the thicker flow deposits are often indurated, especially in their upper thirds. Gas pipe structures are common within the indurated sections. Those gas pipes are often spatially aligned, possibly because they formed from steam percolating through the deposits from buried streams or rivers.

By far the majority of pyroclastic flow deposits occur north of the caldera (Fig. 6). Where thicker than $50 \mathrm{~m}$, the deposit is strongly internally layered, mainly with 1-to-5meter thick, massive layers inter-bedded with 1-to-5-meter thick, strongly cross-bedded and finely laminated layers. Lithics in many of the stratified layers are imbricated, and some of those layers contain accretionary lapilli. At base is $>5$ meters of coarse breccia that contains more than 50\% lithics, many of which are larger than 1 meter. That breccia extends up to $\sim 8 \mathrm{~km}$ to the north of the caldera, where it thins to $\sim 1 \mathrm{~m}$ (Fig. 2). At those more northerly sites the breccia lies in the middle of the deposit, indicating that the 50 meters near the caldera is a minimum. Except for that breccia, scoria-rich flow deposits between the northern caldera rim and the Tugamak Range are massive, poorly sorted, and 
contain $\sim 25-29$ wt. \% lithics (Table 1). No base was found, but more than 30 meters were exposed at many sites (Fig. 6).

On the north side of the main east-west ridge of the Tugamak Range Scoria-rich pyroclastic flow deposits are only $10-30 \mathrm{~cm}$ thick, stratified, and cap thin $(3-5 \mathrm{~mm})$ dacitic ash and pumice layers (Fig. 2). The ridge deposits have well-sorted unimodal upper parts and bimodal, finer grained lower parts (Fig. 7). Those two layers also have separate well-defined modes of scoria and lithics (plus glass) and, overall, contain $\sim 22-30$ wt.\% lithics (Table 1). Scoria-rich deposits thicken from $3.5 \mathrm{~m}$ near the head of one valley within the Tugamak Range to more than 30 meters in the deeper parts of the valleys (Fig. 8-9). Within the valleys, deposits are relatively flat-topped and appear to have filled the valleys (Fig. 2). Those thicker deposits are poorly sorted and appear exactly like those south of the Tugamak Range, except that they are distinctly poorer in lithics (Fig. 10). On smaller ridges extending north in the Tugamak Range, only thin layers were deposited, but those are poorer sorted than the ridge layers (Fig. 9).

To the northeast of the caldera, the Scoria-rich deposits show similar stratigraphic relations as those within the Tugamak Range. Just to the east of the Tugamak Range, we find deposits that mimic those of the ridge deposits (Fig. 7). Further to the northeast, we find 3-9 meters of massive, poorly sorted deposits on the Bering Sea coast (Fig. 4) and on the flanks of Shishaldin Volcano (Fig. 6), all of which appear similar to those in the valleys of the Tugamak Range.

Scoria-Rich Pyroclastic Fall Deposits 
The other unit of the Scoria-rich deposits is a pyroclastic fall layer that is distributed to the east and south of the caldera (Fig. 11). This unit is thickest near the eastern caldera wall, where it is up to $\sim 40-50 \mathrm{~cm}$ thick, and caps the North Pumice fall layer to the east of the caldera. Thin scoria ash exists at the base of the eruptive sequence beneath South Pumice to the west of the caldera, whereas it caps the South Pumice in the southern half of the island (Fig. 5). Scoria-rich fall deposits are well to poorly sorted, with poorer sorting arising from inclusion of fine ash (Table 1). Given its fan-shaped distribution, sorting, coarseness, and fine ash content, we believe that the fall layer represents a mixed deposit from a relatively large buoyant eruption plume and co-ignimbrite ash from the pyroclastic flows.

Thus, during the Scoria-rich phase of the Fisher Tuff eruption, both pyroclastic flows and buoyant eruption plumes (pyroclastic falls) were generated. Isopachs of the fall layer indicate that it represents at least $0.5 \mathrm{~km}^{3}$ of tephra $\left(\sim 0.2 \mathrm{~km}^{3} \mathrm{DRE}\right)$, which is a minimum because of the limited aerial extent of our measured sections. Estimating the volume of the pyroclastic flow deposit is more difficult, because its base is rarely exposed. Stelling et al. (2005) arrived at a minimum of $\sim 10 \mathrm{~km}^{3}$ DRE by assuming given thicknesses of the tuff over the area that it covers on land. It is likely, however, that a significant volume went out to sea, given that the flow deposits are up to $>30$ meters thick near the coast. Using the shape and collapse depth of the caldera Stelling et al. (2005) estimated a volume of $\sim 100 \mathrm{~km}^{3}$ for the Fisher Caldera. It is likely that the volume of the Scoria-rich pyroclastic flow deposits is somewhere in between. This implies that the Scoria-rich fall layer represents only $\sim 0.2-2 \%$ of the mass erupted during this phase of the eruption. 


\section{South Pumice Deposits}

The South Pumice is found only to the south and southwest of the caldera, and is thickest at the southern rim (Fig. 12). It consists of multiple layers that can be grouped into three units. At base, there is a unit of 3-5 alternating layers of fines-poor, moderately sorted layers and poorly sorted layers, with the uppermost one being rich in accretionary lapilli. This unit thins from $\sim 75 \mathrm{~cm}$ at the caldera rim to $\sim 20 \mathrm{~cm}$ only $\sim 6 \mathrm{~km}$ away. The middle unit is a coarse, moderately sorted pumice-rich layer that is found only within $\sim 2$ $\mathrm{km}$ of the caldera rim, where it reaches $\sim 40-60 \mathrm{~cm}$ thick. The upper unit is a well to poorly sorted, pumice-rich deposit, which is the thickest and coarsest of the three units, and appears to be distributed to the south and east. Lithics in this layer are coarser in the south, but remain coarse as the layer thins to the east (Fig. 12). At the rim, the deposit is densely welded, but welding diminishes rapidly and is absent $>1-2 \mathrm{~km}$ away.

It is difficult to interpret the eruptive style of the South Pumice because of its limited distribution. We suggest that the lower unit represents multiple small pyroclastic fall and pyroclastic flow deposits, which is in turn overlain by a relatively coarse pyroclastic fall layer, overlain by a pyroclastic flow deposit. There is too little data to estimate the volume of the South Pumice.

\section{DISCUSSION}

Stelling et al. (2005) established that three magmas were tapped during the Fisher Tuff eruption. We have found that the resulting deposits are distributed differently around the caldera. The North Pumice consists mainly of a pyroclastic fall layer, whereas both the Scoria-rich and South Pumice deposits consist of multiple pyroclastic flow and 
fall deposits. Below we discuss the sequence, dynamics, and vent evolution of the Fisher Tuff eruption, and the transport and deposition of the Scoria-rich pyroclastic flows.

\section{Dynamics and Vent Evolution of the Fisher Tuff Eruption}

Where exposed, the North Pumice is always at the base of the Fisher Tuff, and is usually overlain by a Scoria-rich layer (Figs. 4-5). In contrast, the South Pumice underlies Scoria-rich fall at some sites, but is bracketed by Scoria-rich deposits at others (Fig. 5). Based on this sequence, we suggest that the Fisher Tuff event started with the eruption of North Pumice, after which Scoria-rich deposits erupted, during which the South Pumice erupted.

To constrain the eruption dynamics of the North Pumice, we use isopleths constructed for the largest lithic sizes at the base and top of the deposit (Fig. 13). Those isopleths indicate eruption column heights of $16 \mathrm{~km}$ and $22 \mathrm{~km}$, respectively (Carey and Sparks, 1986). Such column heights would be produced by eruptive intensities of $\sim 1-3 \times 10^{7} \mathrm{~kg} \mathrm{~s}^{-1}$ (Sparks, 1986). Although those are rough estimates, because of the amount of extrapolation needed to complete isopleth shapes, a column height of $\sim 22 \mathrm{~km}$ is consistent with an erupted magma volume of $\sim 0.2 \mathrm{~km}^{3}$, based on the characteristics of other sub-Plinian to Plinian eruptions (Carey and Sigurdsson, 1989). The small pyroclastic flow in the North Pumice suggests that the eruption was partially unstable.

The switch from North Pumice to Scoria-rich deposits was abrupt, as we found few deposits that contain significant proportions of both pumice and scoria. The Scoria-rich deposits consist of both flows and falls. In some cases, we find the fall layer underlying flow deposits, and in others it occupies the same stratigraphic position (e.g., Fig. 5). It is 
thus likely that pyroclastic flows and falls were erupted at the same time. Indeed, we note that the fall layer contains a significant fraction of fine ash (Fig. 4), which suggests that these layers represent a mixed deposit of tephra from a relatively large buoyant eruption plume and from a co-ignimbrite plume from the scoria-rich density currents. Such simultaneous eruption of flows and falls has been recognized in other eruptive sequences (e.g., Fierstein and Hildreth, 1992; Scott et al., 1996; Wilson and Hildreth, 1997).

Lithic sizes in the Scoria-rich fall layer are typically larger than those in the underlying North Pumice (Fig. 13). This indicates that the column height of the Scoriarich plume (from which the large lithics likely originate) reached higher than $22 \mathrm{~km}$. Mass flux of the Scoria-rich phase of the Fisher Tuff (density currents and falls) was thus at least $\sim 10^{7} \mathrm{~kg} / \mathrm{s}$, and probably much greater, considering that $>98 \%$ of the erupted mass went into the flows. There is too little data to constrain intensities for the South Pumice phase of the eruption, but we note that it wavered in character before appearing to increase in intensity.

The distribution and maximum lithic sizes of the North Pumice suggest that it vented from the eastern half of the caldera (Fig. 3). Welding of the upper part of the fall layer on the eastern caldera rim, even in the absence of any overlying flow deposit, suggests that its vent was very near the eastern rim (e.g., Sparks and Wright, 1979). The distribution and maximum lithic sizes of the Scoria-rich fall layer suggest that it also vented from the eastern half of the caldera (Fig. 11). The thicknesses and welding of the Scoria-rich pyroclastic flow deposits suggest that they vented from near the northern caldera wall (Fig 6). The relatively thin yet welded scoria-rich tuff to the west (Fig. 5) may, however, 
have vented from that area. The South Pumice erupted from the western half of the caldera (Stelling et al., 2005). Welding of the South Pumice is, in fact, restricted to the southwest margin of the caldera, implying a vent very near that area. South Pumice overlies debris avalanche deposits (Fig. 5), which may record partial collapse of either the caldera or the source vent of the South Pumice. The only other potential evidence for the timing of caldera collapse during the Fisher Tuff eruption is the lithic breccia within the Scoria-rich pyroclastic flow deposits.

\section{Asymmetric Fountaining of the Scoria-Rich Eruption}

To the north and northwest of the caldera Scoria-rich pyroclastic flow deposits tend to be $>20$ meters thick (Fig. 6). Outside of that region, those deposits are thinner and more sporadic. In fact, further than $\sim 2 \mathrm{~km}$ away from the caldera to the east, southeast, and south margins of the caldera, only North Pumice, South Pumice, and Scoria-rich fall layers are found. It seems unlikely that thick pyroclastic flow deposits would erode from those areas, while much thinner fall layers remained intact, and so we believe that the asymmetric distribution of Scoria-rich pyroclastic flow deposits reflects their original deposition (Fig. 6).

In other asymmetric pyroclastic flow deposits, surrounding topography probably channeled pyroclastic flows in certain directions, such as the 1912 eruption of Katmai (Hildreth, 1983), the Laacher See ignimbrite (Schumacher and Schminke, 1990), and the 1980 eruption of Mount St. Helens (Rowley et al., 1981). In the case of the Fisher Tuff, however, most large pre-caldera volcanic features were actually in the northwest and west areas of the caldera, with essentially none to the southeast (Stelling et al., 2005). 
That argues against the Scoria-rich pyroclastic flows being funneled to the north by large topographic barriers.

It thus seems that the Scoria-rich flows were directed rather than being channeled to the north and northwest. One explanation for why the flows could have been directed that way is that the eruptive jet generating the flows was forced to collapse that way by strong winds. Such winds would have to differ in direction from those at $\sim 20 \mathrm{~km}$ altitude that blew the major fall deposits to the east (Figs. 3, 11). Wind velocity often differs with height (e.g., Sarna-Wojcicki et al., 1981), and so upper level winds could have been to the east, while lower level winds (where collapse is expected to occur) were to the north.

It has been shown that weak eruption columns can be bent if wind speed greatly exceeds their rise rate (Carey and Sparks, 1986). A collapsing fountain, however, occurs in the jet regime, before the erupted mass becomes buoyant. By estimating the amount of bending caused by strong winds of the momentum-driven jet, we can assess whether it collapsed entirely to the leeside of the wind. How much such a jet can be deflected by wind depends on the ratio $(r)$ of jet momentum to wind momentum:

$$
r=\frac{U_{j}}{U_{w}} \sqrt{\frac{\rho_{j}}{\rho_{w}}}
$$

where $\rho_{w}$ and $\rho_{j}$ are densities of wind and the jet, and $U_{w}$ and $U_{j}$ are velocities of wind and the jet (Muppidi and Mahesh, 2005). The minimum upward speed of the jet is given by

$$
U_{j}=(3.09-0.17 n) M^{1 / 5}
$$

where $n$ is the mass fraction of gas and $M$ is mass flux (Kaminski and Jaupart, 2001), and the density of the erupted mass in the jet is 


$$
\frac{1}{\rho_{j}}=\frac{1-n}{\rho_{p}}+\frac{n}{\rho_{g}}
$$

where $\rho_{g}$ and $\rho_{p}$ are densities of gas and particles (Woods, 1988). The trajectory of the bending jet can be described by its horizontal displacement caused by the wind $(x)$ at each height $(z)$ :

$$
z \cong 2 r\left(\frac{x}{r}\right)^{0.33}\left(\frac{2 \delta}{3 d}+\frac{0.05 \pi}{4} r^{2}\right)^{0.15}
$$

where $\delta$ is the wind boundary layer and $d$ is vent diameter (Muppidi and Mahesh, 2005). We scale both $x$ and $z$ by conduit diameter, and assume that $\rho_{w}=1.2 \mathrm{~kg} \mathrm{~m}^{-3}, \mathrm{n}=0.05, \rho_{g}$ $=0.9 \mathrm{~kg} \mathrm{~m}^{-3}, \rho_{p}=2500 \mathrm{~kg} \mathrm{~m}^{-3}$, and $\delta=200 \mathrm{~m}$ (for a smooth surface; Turner, 1970). We also assume that $z / d=10$ because fountaining has been calculated to restrict the jet propagation to $\sim 10$ vent diameters above the crater (Bursik and Woods, 1991; Neri and Macedonio, 1996). We let vent diameter vary between 0.2 and $9 \mathrm{~km}$ (i.e. medium size conduit to caldera diameter), wind speed vary between 50 and $100 \mathrm{~m} / \mathrm{s}$, and mass flux vary between $10^{6}$ and $10^{10} \mathrm{~kg} / \mathrm{s}$ (Fig. 14). We find that the horizontal displacement of the jet at its fountaining height is less than one conduit diameter for high mass fluxes (e.g., $10^{9} \mathrm{~kg} / \mathrm{s}$ ), regardless of wind speed and vent size. At low mass fluxes (e.g., $10^{6} \mathrm{~kg} / \mathrm{s}$ ), however, the jet can be deflected significantly, up to 20 conduit diameters.

Assuming that deflection must exceed 2-3 vent diameters to cause unidirectional fountaining, winds would have to have blown in excess of $\sim 60-70 \mathrm{~m} / \mathrm{s}$ during the Fisher Tuff eruption (Fig. 14). In fact, much stronger winds would likely need to have blown, because mass flux during the Scoria-rich phase was likely higher than our estimate, as discussed above. Moreover, displacements given by (4) are maxima, because $U_{j}$ is likely a minimum and because we neglect any possible overpressure of the jet. Although such 
winds are not unreasonable, we do not believe this likely, because those high winds would need to have died down to allow the South Pumice flows to travel to the south, and yet restart just when the Scoria-rich phase began again. Wind can be highly unstable, but it seems too fortuitous that it would blow only when scoria erupts.

Instead, we believe that the Scoria-rich pyroclastic flows were directed to the north because the conduit that fed the column was inclined to the north (Fig. 15). Because the jet would be inclined, its gravitational collapse would be asymmetric. In the case of the Fisher Tuff, fountaining was displaced to the north, and hence the thickest deposits, internal stratification, lithic breccia, and greatest welding are all found to the north of the caldera. The inclined conduit may have resulted from asymmetric block faulting as the caldera collapsed, which is supported by the complex evolution of vents.

Inclined conduits have been recognized in single-vent, small-volume eruptions (e.g., Stromboli, Chouet et al. 2003; Unzen, Umakoshi et al., 2001; Montaña Blanca, Folch and Felpeto, 2005). But, except for cases where topography acts as channels, caldera-forming eruptions often produce relatively axisymmetric deposits (e.g., Okmok, Burgisser, 2005; Kos Plateau Tuff, Allen, 2001; Tambora, Sigurdsson and Carey, 1989; Pinatubo, Scott et al., 1996), which suggests they were fed by vertical conduits. To our knowledge, the Fisher Tuff is the first example in which a large eruption involving caldera collapse was fed by an inclined conduit.

\section{Transport and Deposition of the Fisher Tuff Pyroclastic Flows}

A key to understanding the mechanics of the Scoria-rich pyroclastic flows is their deposits on the main ridge of the Tugamak Range and on its eastern side. (Fig. 7). We 
doubt the thin deposits are the eroded remnants of thicker flow deposits, because it seems unlikely that only thick deposits would be eroded, whereas thin layers, including underlying dacite fall layers, survived. We also would not expect erosion to leave a consistent stratigraphy across the ridges and to the east (Fig. 7). Although their sorting is similar to fall layers, the ridge deposits are as coarse as the fall layer at the caldera wall and as rich in lithics as flow deposits nearer the caldera (Fig. 10). Both of those characteristics argue against them being fall deposits (Plinian or co-ignimbrite). We thus interpret the layers on the ridges of the Tugamak and on its eastern border as veneer deposits from pyroclastic flows.

As expected, such veneer deposits are difficult to reconcile with a model that relies on deposition from only a dense, momentum-driven flow (Miller and Smith, 1977; Legros and Kelfoun, 2000). In particular, such a model cannot explain the absence of thick, massive deposits near the eastern border of the Tugamak Range nor, for that fact, their absence from the ridge on the Tugamak Range. Instead, we favor a model of densitystratified flow fed by an asymmetrically fountaining eruption (Fig. 15). As discussed earlier, grain-size distributions and stratigraphic relations indicate that the fountaining eruption produced both a buoyant plume and pyroclastic flows, but we note that $>98 \%$ of the mass went into the flows. Internal depositional layering (cross bedding and lithic imbrication) and the coarse lithic breccia near the caldera rim are signs of highly unsteady deposition. Tephra falling from a fountaining eruption is either re-entrained upwards by the jet or fed into a lateral pyroclastic flow (Neri and Macedonio, 1996; Todesco et al., 2002). Re-entrainment creates a highly unstable recirculation zone that causes irregular feeding of the flow. As the flow traveled north away from the feeding 
zone, it would develop a concentration gradient and stratify into a dense undercurrent and an over-riding dilute turbulent cloud (e.g., Valentine, 1987; Fisher, 1990; Druitt, 1998; Burgisser and Bergantz, 2002). The denser boundary layer at the base would produce massive, poorly sorted deposits (Fig. Model).

It is thus reasonable to assume that when the scoria-rich pyroclastic flow reached the Tugamak Range it was consisted of a dense undercurrent and an over-riding turbulent cloud. When the flow ran into the Tugamak Range, however, the ridge profoundly modified the highly concentrated boundary layer. The stratified current is unlikely to have maintained its integrity while ramping up the mountain range, because this would most likely have caused backflow of the high-concentration part (Fisher, 1990). This plus the absence of erosion on the ridge top, the abrupt loss of lithics across the ridge, and the presence of well-sorted veneer deposits all suggest that the vertical concentration gradient was significant and that the dense boundary layer was completely stripped off (Fig. 15). The division between the dilute transport system, which is unaffected by the ground, and the undercurrent, where most deposition occurs, disappeared when the Tugamak Range blocked the undercurrent and let the turbulent cloud continue over the ridge.

On the ridge, the relatively coarse, well-sorted nature of the veneer deposits suggests they formed by aggradation of suspended tephra that could no longer be supported by the most energetic eddies of the turbulent cloud (Burgisser, 2005). The stripped flow thus had a distribution of particles strongly controlled by the turbulent gas, and deposition on the ridge was from suspended load fallout (Burgisser and Bergantz, 2002, Druitt et al., 2002). The veneer deposits east of the Range could either suggest that the Tugamak 
Range also deflected undercurrents away from its sides or that the edges of the flow coincided with the eastern margin of the Range.

The ridge veneer deposits have well-defined coarse modes for scoria and lithics (Fig. 7). Assuming those modes result from suspended load fallout, we can calculate the average speed of the turbulent cloud as it passed over the ridge, following the method of Burgisser (2005). Briefly, that model uses a combination of two dimensionless numbers (the Stokes number and what we call the Stability number) to determine speeds and sizes of supporting eddies. The Stokes number $\left(S_{T}\right)$ is the ratio of pyroclast response time $\left(U_{T} / g\right.$, where $U_{T}$ is the particle terminal fall velocity and $g$ is gravitational acceleration) to eddy rotation time, and the Stability number $\left(\Sigma_{T}\right)$ is the ratio of $U_{T}$ to eddy rotation speed (Burgisser and Bergantz, 2002). For each size mode (scoria and lithic), pyroclasts with sizes within one standard deviation of the mode are assumed to be deposited by supporting eddies in which $S_{T}=1$ and $\Sigma_{T}=1$ (i.e., eddies with speeds equal to the terminal fall speed of that size). We find that coarser upper parts of the veneer deposits yield current speeds ( $\sim 3.2$ times supporting eddy speed; Burgisser and Bergantz, 2002) of 78 to $142 \mathrm{~m} / \mathrm{s}$, whereas the lower parts yield speeds of 43 to $82 \mathrm{~m} / \mathrm{s}$ (Fig. 16). Uncertainties, estimated from differences in speeds for the two modes, are 10-38\%. Particle aggregation or slower speeds may account for the secondary mode of fine ash in the lower parts of the veneer deposits (Fig. 7). Overall, the veneer deposits indicate that eddies depositing the upper layer were 30 to $320 \mathrm{~m}$ tall, and those for the lower layer were 16 to $200 \mathrm{~m}$ tall. We thus find that the Scoria-rich deposits record the passing of a pyroclastic flow that was significantly taller than the Tugamak Range. 
As the current continued north, it stratified anew, producing another undercurrent, and thus deposits become thicker and richer in fine ash until eventually appearing like deposits south of the ridge (Fig. 8). Generation of this second undercurrent from a dilute, light-component-enriched part of the original flow is consistent with the deposits north of the main ridge being distinctly poorer in lithics compared to those to the south (Fig. 10).

Our model is thus of a density stratified turbulent flow that travels north from the caldera and interacts with the Tugamak Range (Fig. 15). The Campanian Tuff (Fisher et al., 1993), the Laacher See Tephra (Schumacher and Schminke, 1990), and Okmok Caldera (Burgisser, 2005) are other examples where topography strongly controlled deposition of density stratified flows. In the case of the Campanian Tuff, the flow was partly blocked by high ridges, and much thicker deposits are found in valleys than on local ridge tops, because of secondary flowage off of the ridges (Fisher et al., 1993). In the Tugamak Range, we also find significantly thicker valley deposits compared to those on ridges, which may indicate some gravity-driven flowage. At Okmok caldera, veneer deposits found on ridge tops have grain-size distributions that match the coarsest half of nearby valley-filling deposits (Burgisser, 2005). That relationship, similar to that at Fisher (Fig. 8), also led to the conclusion that veneer deposits originated from suspended load fallout.

Our model suggests that the Scoria-rich pyroclastic flows segregated in less than 15 $\mathrm{km}$ from the caldera, and probably even less than $6 \mathrm{~km}$ (Fig. 15). At Okmok caldera, the distance between the first ridge top and the caldera rim suggests flows segregated in less than $10 \mathrm{~km}$ (Burgisser, 2005). That same distance is only a couple kilometers at Laacher See (Schumacher and Schminke, 1990). Fast stratification of fountaining-generated 
pyroclastic density currents thus appears common. But, can turbulent clouds stripped of their undercurrents re-stratify as fast? At Montserrat, much smaller pyroclastic flows took $\sim 3-5 \mathrm{~s}$ and $\sim 28 \mathrm{~s}$, respectively, to form dense undercurrents that were able to sediment massive deposits (Druitt et al., 2002). At Fisher, the distance between the veneer deposits and the thick, poorly-sorted deposits in the valleys of the Tugamak Range is only 1-2 km (Fig. 8). Using our estimated speeds of the dilute cloud at the ridge (Fig. 16), we calculate that a dense undercurrent was re-generated in 7 to $26 \mathrm{~s}$, on a time scale is similar to that at Montserrat. It thus appears that segregation is only a weak function of the total volume of material transported by the currents.

Stratification of flows can also be assessed using veneer deposits deposited after the flows interacted with a body of water. In the1883 Krakatau eruption (Mandeville et al., 1996), pyroclastic flows developed such strong vertical concentration gradients that they split at the shoreline into a denser subaqueous part and a more dilute subaerial part. The subaerial current remained dilute (less dense than water) for up to $40 \mathrm{~km}$ from source, when it reached land and left veneer deposits (Carey et al., 1996). There is no indication of whether it reformed a dense boundary layer. At Kos, relatively dilute flows that crossed water did produce valley-filling deposits on the Turkish coast, and thus they reformed a dense boundary layer in less than $12 \mathrm{~km}$ (Allen and Cas, 2001). In contrast, at Okmok extensive veneer deposits left by the flow after it crossing an 8-km strait between islands suggest the flow lost its undercurrent to the water, but was unable to recreate one before running out after more than $20 \mathrm{~km}$ inland (Burgisser, 2005).

The emerging picture is that pyroclastic flows segregate rapidly, regardless of their size (from $<0.1 \mathrm{~km}^{3}$ to $>10 \mathrm{~km}^{3}$ ) and fountaining geometry. If the dense boundary layer 
is thick enough, it forms an underflow that strongly reacts to encounters with topography or the sea. If the underflow is blocked, then the current generally continues its course with a weak concentration gradient and low depositional rate. Segregation, however, does not always recur in such stripped flows. In some cases, the concentration gradient completely fails to reestablish before run-out, but in others, like the Fisher Tuff, the undercurrent regenerates in a matter of seconds. Given that veneer deposits in the Fisher Tuff are much coarser than for example those at Montserrat, but have similar grain sizes as those at Okmok caldera, we suggest undercurrent generation is independent of the grain-size distribution of the stripped flow and its eruption size. Further study is needed to determine the controls of secondary segregation.

\section{CONCLUSIONS}

The stratigraphy of the Fisher Tuff suggests a complex eruptive sequence that started with a Plinian column of $18-22 \mathrm{~km}$ height that was blown east. This partly unstable column produced the $\sim 0.2 \mathrm{~km}^{3}$ DRE North Pumice deposits. The eruption then switched abruptly to a mixed basalt-dacite composition, producing Scoria-rich deposits. At some point during that phase of the eruption, a separate batch of dacite erupted from the western half of the caldera, producing the South Pumice. The Scoria-rich deposits consist of co-erupted pyroclastic flows and falls. The buoyant plume reached more than $22 \mathrm{~km}$ in height and was blown east, whereas most pyroclastic flows traveled to the north and northwest.

In the absence of topographic control, we suggest the strongly asymmetric distribution of the Fisher Tuff around the caldera implies that Scoria-rich pyroclastic 
flows were directed to the north. As this directed eruption cannot be explained by wind effects, we suggest that the conduit that fed the column was inclined to the north. This explanation makes the Fisher Tuff the first example of an inclined conduit feeding a >10 $\mathrm{km}^{3}$ DRE eruption involving caldera collapse, and suggests subsurface geometry of the conduit controls the area affected by an eruption as much as does surrounding topography, regardless of eruption size.

On their way to the north, the pyroclastic flows crossed over the 500-700 m high Tugamak Range, $\sim 15 \mathrm{~km}$ away from the caldera. Changes in deposits before, on, and after the Tugamak Range are best explained by a flow that was stratified into a dense undercurrent and an over-riding dilute turbulent cloud. Deposition before the Tugamak Range was mainly from the undercurrent. When the current ran into the Range, the ridge blocked the undercurrent, but let the turbulent cloud continue on over the ridge. Deposition on the ridge was thus directly from the lower part of the turbulent cloud as suspended load fallout. As the flow continued north, it stratified anew, creating another undercurrent in 7-26 s. This interpretation implies that the Fisher Tuff records the passing of a flow that was able to quickly segregate twice. We believe this conclusion, which differs from that of Miller and Smith (1977), reflects recent developments in our views of the inner workings of pyroclastic flows, as well as the importance of finding thin remnants of the passing of the dilute cloud.

\section{ACKNOWLEDGEMENTS}

This research was generously supported by the Alaskan Volcano Observatory and a research grant to J.G. from the National Science Foundation (EAR-0401784). We thank 
John Eichelberger, Terry Keith, and Tom Murray for their support of our work at Fisher Caldera. The manuscript was greatly improved by thorough reviews by Peter Kokelaar and an anonymous reviewer. 


\section{REFERENCES}

Allen, S.R. (2001) Reconstruction of a major caldera-forming eruption from pyroclastic deposit characteristics: Kos Plateau Tuff, eastern Aegean Sea, Journal of Volcanology and Geothermal Research, v.105, p. 141-162.

Allen, S.R., and Cas, R.A.F. (2001) Transport of pyroclastic flows across the sea during the explosive, rhyolitic eruption of the Kos Plateau Tuff, Greece, Bulletin of Volcanology, v.62, p. 441-456.

Baxter, P.J. (2000) Impacts of eruptions on human health. In, Sigurdsson, H. (ed) Encyclopedia of Volcanoes, Academic Press, San Diego, p. 1035-1044.

Boudon, G., Camus, G., Gourgaud, A., and Lajoie, J. (1993) The 1984 nuée-ardente deposits of Merapi volcano, Central Java, Indonesia: stratigraphy, textural characteristics, and transport mechanisms, Bulletin of Volcanology, v.55, p. 327-342.

Branney, M.J., and Kokelaar, P. (1992) A reappraisal of ignimbrite emplacement; progressive aggradation and changes from particulate to non-particulate flow during emplacement of high-grade ignimbrite. Bull. Volcanol., v. 54(6), p. 504-520.

Branney, M.J., and Kokelaar, P. (2002) Pyroclastic density currents and the sedimentation of ignimbrites, Geological Society, London, Memoirs, v.27, 152 p.

Burgisser A, Bergantz GW (2002) Reconciling pyroclastic flow and surge: the multiphase physics of pyroclastic density currents. Earth Planet Sci Lett 202:405-418

Burgisser, A. (2005) Physical volcanology of the 2050 BP caldera-forming eruption of Okmok volcano, Alaska, Bulletin of Volcanology, v. 67, p. 497-525.

Burgisser, A., and Gardner, J.E. (2006) Using hydraulic equivalences to discriminate transport processes of volcanic flows, Geology, v.34, p. 157-160.

Bursik, M.I., and Woods, A.W. (1991) Buoyant, superbuoyant and collapsing eruption colums, Journal of Volcanology and Geothermal Research, v.45, p. 347-350.

Carey, S., and Sigurdsson, H. (1989) The intensity of plinian eruptions, Bulletin of Volcanology, v. 51, p. 28-40.

Carey, S.N., Sparks, R.S.J. (1986) Quantitative models of the fallout and dispersal of tephra from volcanic eruption columns. Bull. Volcanol., v. 48, p. 109-125.

Carey, S., Sigurdsson, H., Mandeville, C., and Bronto, S. (1996) Pyroclastic flows and surges over water: An example from the 1883 Krakatau eruption. Bull. Volcanol., v. 57, p. 493-511.

Carrasco-Nunez, G., and Branney, M.J. (2005) Progressive assembly of a massive layer of ignimbrite with a normal-to-reverse compositional zoning: the Zaragoza ignimbrite of central Mexico, Bulletin of Volcanology, v.68, p. 3-20.

Cas RAF, Wright JV (1987) Volcanic successions: modern and ancient. Allen \& Unwin, London, 528p

Chouet, B.A., Dawson, P.B., Ohminato, T., Martini, M., Saccorotti, G., Giudicepietro, F., De Luca, G., Milana, G., and Scarpa, R. (2003) Source mechanisms of explosions at Stromboli volcano, Italy, determined from moment-tensor inversions of very-longperiod data. J. Geophys. Res., v. 108, doi:10.1029/2002JB001919

Choux, C., Druitt, T., and Thomas, N. (2004) Stratification and particle sergegation in flowing polydisperse suspensions, with applicatiopns to the transport and sedimentation of pyroclastic density currents, Journal of Volcanology and Geothermal Research, v.138, p. 223-241. 
Cordoba, G. (2005) A model of the pyroclastic flow dynamics at Galeras Volcano, Colombia, Journal of Volcanology and Geothermal Research, v.139, p. 59-71.

Dobran, F., Neri, A., and Macedonio, G. (1993) Numerical simulation of collapsing volcanic columns, Journal of Geophysical Research, v.98, p. 4231-4259.

Dobran, F. (2001) Volcanic processes, Kluwer Academic, New York, 590 p.

Druitt TH (1998) Pyroclastic density currents. In: Gilbert JS, Sparks RSJ (eds) The physics of explosive volcanic eruptions. Geological Society Special Publication, vol 145. Geological Society, London, 145-182.

Druitt, T.H., Calder, E.S., Cole, P.D., Hoblitt, R.P., Loughlin, S.C., Norton, G.E., Ritchie, L.J., Sparks, R.S.J., Voight, B. (2002) Small-volume, highly mobile pyroclastic flows formed by rapid sedimentation from pyroclastic surges at Soufrière Hills Volcano, Montserrat: an important volcanic hazard, in: Druitt, T.H. and Kokelaar, B.P. (eds) The eruption of Soufriere Hills Volcano, Montserrat, from 1995 to 1999, Geological Society, London, Memoirs, v. 21, p. 263-279.

Fierstein, J., and Hildreth, W. (1992) The plinian eruptions of 1912 at Novarupta, Katmai National Park, Alaska. Bull. Volcanol., v. 54, p. 646-684.

Fierstein, J., and Nathenson, M. (1992) Another look at the calculation of fallout tephra volumes. Bull. Volcanol., v. 54, p. 156-167.

Fisher, R.V. (1990) Transport and deposition of a pyroclastic surge across an area of high relief: The 18 May 1980 eruption of Mount St. Helens, Washington. Geol. Soc. Am. Bull., v. 102, p. 1038-1054.

Fisher R.V., Orsi G., Ort M., and Heiken G. (1993) Mobility of a large-volume pyroclastic flow - emplacement of the Campanian ignimbrite, Italy. J Volcanol Geotherm Res 56:205-220.

Folch, A., and Felpeto, A. (2005) A coupled model for dispersal of tephra during sustained explosive eruptions, Journal of Volcanology and Geothermal Research, v.145, p. 337-349.

Freundt, A., and Schmincke, H.-U. (1985) Lithic-enriched segregation bodies in pyroclastic flow deposits of Laacher See volcano (East Eiffel, Germany), Journal of Volcanology and Geothermal Research, v.25, p. 193-224.

Hildreth, W. (1983) The compositionally zoned eruption of 1912 in the Valley of Ten Thousand Smokes, Katmai National Park, Alaska. J. Volcanol. Geotherm. Res., v. 18 , p. $1-56$.

Inman DL (1952) Measures for describing the size distribution of sediments. J Sediment Petrol 22:125-145

Kaminski, E., and Jaupart, C. (2001) Marginal stability of atmospheric eruption columns and pyroclastic flow generation, Journal of Geophysical Research, v.106, p. 2178521798.

Legros, F., and Kelfoun, K. (2000) On the ability of pyroclastic flows to scale topographic obstacles, Journal of Volcanology and Geothermal Research, v.98, p. 235-241.

Mandeville, C.W., Carey, S., and Sigurdsson, H. (1996) Sedimentology of the Krakatau 1883 submarine pyroclastic deposits, Bulletin of Volcanology, v.57, p. 512-529.

Miller, T.P., Smith, R.L. (1977) Spectacular mobility of ash flows around Aniakchak and 
Fisher calderas, Alaska. Geology, v. 5, p. 173-176.

Muppidi, S., and Mahesh, K. (2005) Study of trajectories of jets in crossflow using direct numerical simulations, Journal of Fluid Mechanics, v.530, p. 81-100.

Neri, A., and Macedonio, G. (1996) Numerical simulation of collapsing volcanic columns with particles of two sizes, Journal of Geophysical Research, v.101, p. 8153-8174.

Pyle, D.M. (1989) The thickness, volume and grainsize of tephra fall deposits, Bulletin of Volcanology, v.51, p. 1-15.

Rowley, P.D., Kuntz, M.A., and MacLeod, N.S. (1981) Pyroclastic-flow deposits. In Lipman, P. and Mullineaux, (eds.) The 1980 eruptions of Mount St. Helens, Washington, U.S. Geol. Surv., Prof. Pap. 1350, 489-512.

Sarna-Wojcicki, A.M., S. Shipley, R.B. Waitt, Jr., D. Dzurisin, and S. H. Wood (1981) Areal distribution, thickness, mass, volume, and grain-size of air-fall ash from the six major eruptions in 1980. In Lipman, P. and Mullineaux, (eds.) The 1980 eruptions of Mount St. Helens, Washington, U.S. Geol. Surv., Prof. Pap. 1350, 577-600.

Schumacher, R., and Schmincke, H-U. (1990) The lateral facies of ignimbrites at Laacher See volcano, Bulletin of Volcanology, v.52, p. 271-285.

Scott, W.E., Hoblitt, R.P., Torres, R.C., Self, S., Martinez, M.L., and Nillos, T., Jr. (1996) Pyroclastic flows of the June 15, 1991, climactic eruption of Mount Pinatubo, In, Newhall, C.G., Punongbayan, R.S. (eds.) Fire and Mud: Eruptions and Lahars of Mount Pinatubo, Philippines, Univ. Wash. Press, p. 545-570.

Sigurdsson, H., and Carey, S. (1989) Plinian and co-ignimbrite tephra fall from the 1815 eruption of Tambora volcano, Bulletin of Volcanology, v.51, p. 243-270.

Sohn, Y.K. (1997) On traction-carpet sedimentation: Journal of Sedimentary Research, v. 67 , p. 502-509.

Sparks, R.S.J., and J.V. Wright (1979) Welded air-fall tuffs, in Chapin and Elston, Ash Flow Tuffs, Geol. Soc Am. Spec. Pap. 180, 155-166.

Sparks, R.S.J. (1986) The dimensions and dynamics of volcanic eruption columns. Bull. Volcanol., 48, 3-15.

Stelling, P., J.E. Gardner, and J. Beget, Eruptive history of Fisher Caldera, Alaska, USA, Journal of Volcanology and Geothermal Research, v. 139 (3-4), p. 163-183, 2005.

Todesco, M., Neri, A., Esposti Ongaro, T., Papale, P., Macedonio, G., Santacroce, R., and Longo, A. (2002) Pyroclastic flow hazard assessment at Vesuvius (Italy) by using numerical modeling. I. Large-scale dynamics, Bulletin of Volcanology, v.64, p. 155177.

Turner, D.B. (1970): Workbook of atmospheric dispersion estimates. Publication AP-26, (NTIS PB 191 482). Office of Air Programs, U.S. Environmental Protection Agency, $84 \mathrm{p}$.

Valentine G (1987) Statified flow in pyroclastic surges. Bull Volcanol 49:616-630.

Umakoshi, K., Shimizu, H., and Matsuwo, N. (2001) Volcano-tectonic seismicity at Unzen volcano, Japan, 1985-1999, Journal of Volcanology and Geothermal Research, v.112, p. 117-131.

Walker, G.P.L. (1971) Grainsize characteristics of pyroclastic deposits, Journal of Geology, v. 79, p. 696-714.

Wilson, C.J.N., Hildreth, W. (1997) The Bishop Tuff; New insights from eruptive stratigraphy. J. Geol., v. 105, p. 407-439.

Wilson, C.J.N., Walker G.P.L. (1982) Ignimbrite depositional facies: The anatomy of a 
pyroclastic flow. J. Goel. Soc. Lond., v. 139, p. 581-592.

Woods, A.W. (1988) The fluid dynamics and thermodynamics of eruption columns, Bulletin of Volcanology, v.50, p. 169-193. 
Table 1: Grain-size data of Fisher Tuff

\begin{tabular}{|c|c|c|c|c|c|c|c|}
\hline Sample $^{\mathrm{a}}$ & Unit $^{\mathrm{b}}$ & $\mathrm{M}_{\mathrm{d}}^{\mathrm{c}}$ & $\sigma^{\mathrm{c}}$ & Mode $^{\mathrm{c}}$ & Second $^{\mathrm{c}}$ & Lithics $^{\mathrm{c}}$ & Location Description \\
\hline AFI-03B & NP & $-3.25(9.5)$ & 1.15 & $-3.0(8.0)$ & & & $\sim 2.5 \mathrm{~km}$ east of caldera wall \\
\hline AFI-03C & Scoria & $-2.40(5.3)$ & 1.29 & $-2.5(5.66)$ & & & $\sim 2.5 \mathrm{~km}$ east of caldera wall \\
\hline AFI-08B & NP & $1.04(0.38)$ & 2.60 & $3.5(0.09)$ & & 10.7 & $\sim 27 \mathrm{~km}$ northeast of caldera on Bering Sea Coast \\
\hline AFI-08D & NP & $0.97(0.51)$ & 2.52 & $-0.5(1.41)$ & & 13.1 & $\sim 27 \mathrm{~km}$ northeast of caldera on Bering Sea Coast \\
\hline AFI-10A & NP & $0.19(0.88)$ & 0.96 & $0.5(0.71)$ & & & $\sim 36 \mathrm{~km}$ northeast of caldera on Bering Sea Coast \\
\hline AFI-10C & Scoria & $-0.33(1.26)$ & 1.82 & $-0.5(1.41)$ & $4.0(0.06)$ & & $\sim 36 \mathrm{~km}$ northeast of caldera on Bering Sea Coast \\
\hline AFI-13A & Scoria & $-0.51(1.42)$ & 3.31 & $-1.0(2.0)$ & & 28.6 & $\sim 2 \mathrm{~km}$ north of caldera wall \\
\hline AFI-13B & Scoria & $-1.02(2.03)$ & 2.35 & $-1.5(2.83)$ & & 24.9 & $\sim 2 \mathrm{~km}$ north of caldera wall \\
\hline AFI-21D & SP & $-3.67(12.7)$ & 2.04 & $-3.5(11.3)$ & & & $\sim 1.5 \mathrm{~km}$ from southern caldera wall \\
\hline AFI-21E & SP & $-3.76(13.6)$ & 1.82 & $-4.5(22.6)$ & & & $\sim 1.5 \mathrm{~km}$ from southern caldera wall \\
\hline AFI-27A & NP & $-3.41(10.6)$ & 1.86 & $-4.0(16.0)$ & $4.5(0.04)$ & & $\sim 2 \mathrm{~km}$ from southeastern caldera wall \\
\hline AFI-27B & Scoria & $-2.24(4.72)$ & 2.85 & $-3.0(8.0)$ & $3.0(0.13)$ & & $\sim 2 \mathrm{~km}$ from southeastern caldera wall \\
\hline FC-161B & Scoria & $-1.50(2.83)$ & 3.42 & $-2.5(5.66)$ & $5.5(0.02)$ & 27.8 & next to eastern boundary of Tugamak Range \\
\hline FC-162A & Scoria & $-2.42(5.35)$ & 1.04 & $-2.5(5.66)$ & & 25.6 & on main ridge of Tugamak Range \\
\hline FC-162B & Scoria & $-1.50(2.83)$ & 3.06 & $-2.0(4.0)$ & $5.5(0.02)$ & 30.4 & on main ridge of Tugamak Range \\
\hline FC-317A & Scoria & $-1.02(2.03)$ & 2.85 & $-1(2.0)$ & $4.5(0.04)$ & 21.9 & on main ridge of Tugamak Range \\
\hline FC-317B & Scoria & $-2.96(7.78)$ & 1.04 & $-3.5(11.3)$ & & 22.1 & on main ridge of Tugamak Range \\
\hline FC-320D & Scoria & $-1.09(2.13)$ & 3.60 & $-2.5(5.66)$ & $4.5(0.04)$ & & at head of valley in Tugamak Range \\
\hline FC-321B & Scoria & $0.34(0.79)$ & 2.64 & $1.0(0.5)$ & & 14.1 & in valley of Tugamak Range \\
\hline FC-321C & Scoria & $0.00(1.00)$ & 3.11 & $-1.5(2.83)$ & & 8.7 & in valley of Tugamak Range \\
\hline FC-321D & Scoria & $0.15(0.90)$ & 2.97 & $-1.0(2.0)$ & & 9.7 & in valley of Tugamak Range \\
\hline FC-321E & Scoria & $-0.04(1.03)$ & 2.66 & $-1.5(2.83)$ & & 17.9 & in valley of Tugamak Range \\
\hline FC-326A & Scoria & $0.50(0.71)$ & 2.54 & $2.5(0.18)$ & & 13.9 & on small ridge in Tugamak Range \\
\hline FC-327A & Scoria & $-0.79(1.73)$ & 2.62 & $-1.5(2.83)$ & & & in valley of Tugamak Range \\
\hline FC-330A & Scoria & $0.44(0.74)$ & 2.91 & $1.5(0.35)$ & & 27.5 & between Fisher Caldera and Tugamak Range \\
\hline FC-338B & Scoria & $-1.07(0.48)$ & 2.60 & $-1.0(2.0)$ & & & between Fisher Caldera and Tugamak Range \\
\hline FC-339B & Scoria & $-0.06(1.04)$ & 2.96 & $1.5(0.35)$ & & & between Fisher Caldera and Tugamak Range \\
\hline
\end{tabular}




\section{FIGURE CAPTION}

Figure 1. Map showing the position of Fisher Caldera on Unimak Island, Alaska. Sites where the Fisher Tuff was measured and described are shown by filled circles, except for three sites to the northeast on the Bering Sea coast that are between 40 and $50 \mathrm{~km}$ away. Sample sites for grain-size analyses (table 1) and those in other figures are indicated. Dashed line marks the approximate wall of the caldera. Topographic contours are in $100 \mathrm{~m}$ intervals.

Figure 2. a: Aerial photograph looking south at the Tugamak Range and Fisher Caldera. b: Welded Scoria-rich pyroclastic flow and North Pumice exposed at FC-150 (fig. 1). Measuring stick is $2 \mathrm{~m}$ and stands on the base. Color change in North Pumice results from baking by the flow. c: Welded Scoria-rich pyroclastic flow ( $4 \mathrm{~m}$ thick) and North Pumice exposed in eastern caldera wall. d: Scoria-rich pyroclastic flow deposits and 5-mm-thick North Pumice (marked by arrow) in the Tugamak Range (FC-317; fig. 1). Boundary between the two Scoria-rich layers is marked by a dashed line. Measuring stick is $52 \mathrm{~cm}$. e: Scoria-rich pyroclastic flow deposits exposed in a valley of the Tugamak Range (FC-320; fig. 1). Note the relatively flat top of the valley-ponded deposit. f: Scoria-rich pyroclastic flow deposits between Fisher Caldera and the Tugamak Range (in background) (FC-338; fig. 1).

Figure 3. Thicknesses (in $\mathrm{cm}$ ) of North Pumice deposit. Filled circles are sites where the deposit was found. Two sites ( $\varnothing$ ) in the Tugamak Range are noted where the base of the tuff was found, but North Pumice is missing. Solid line is for the well constrained isopach, dashed lines are less constrained isopachs. The approximate location for the vent is shown (star). Dash-dot lines outline the Tugamak Range and Fisher Caldera. 
Figure 4. Representative stratigraphic sections of sites east and northeast of Fisher Caldera (see Figure 1 for site locations). Numbers to the left of each section are thicknesses of individual layers in $\mathrm{cm}$. Grain-size distributions of samples are shown (Table 1). NP=North Pumice.

Figure 5. Representative stratigraphic sections of sites west and south of Fisher Caldera (see Figure 1 for site locations). Numbers to the left of each section are thicknesses of individual layers in $\mathrm{cm}$. NP=North Pumice; SP=South Pumice.

Figure 6: Thicknesses (in m) of Scoria-rich pyroclastic flow deposits. Filled circles are sites where the deposit was found. Dashed line outlines sites where the deposits are partly to densely welded. Dotted line delineates sites where the deposits are typically greater than 20 meters thick. Based on the thickness variations and welding, the vent (star) was probably located in the eastern half of the caldera, and most of the flows went to the north and northwest (heavy dashed arrow), with only minor flows traveling in other directions (thin arrows). Dash-dot lines outline the Tugamak Range and Fisher Caldera.

Figure 7: Correlation of stratigraphic sections across the main east-west ridge of the Tugamak Range, extending to a site at the eastern base of the range (see inset map for locations; contours are $50 \mathrm{~m}$ ). At base are thin layers of dacitic ash and pumice, which thicken to the east, overlain by one or two scoria-rich deposits that are either well sorted or bimodal. Grain-size distributions and componentry are shown (Table 1).

Figure 8: Topographic variations across the middle part of the Tugamak Range, with thicknesses and grain-size distributions of Scoria-rich deposits shown. The 
topographic profile corresponds to the dashed line (drawn directly away from main vent in Fig. 6) in the inset map (50-m contours); filled circles are locations of sites on the profile. Sites not on the profile were projected onto it, using their measured GPS heights. Stratigraphic heights of grain-size samples are noted. Thicknesses for FC316, 317, and 318 are very similar (see Fig. 7); samples from FC-317 are shown. Samples from FC-321 are not distinguished because they overlap each other.

Figure 9: Topographic variations across the eastern part of the Tugamak Range, with thicknesses and grain-size distributions of Scoria-rich deposits shown (see Fig. 8 for details). In addition, gray circles are the projected position and height of two samples from the western part of the Tugamak Range. Their distances were measured from the south end of the profile.

Figure 10: Variations in lithic content (in wt.\%) and medium grain size (and sorting) of the Scoria-rich deposits with distance from caldera rim. Sizes are in $\phi$ units and in mm (Table 1). Open symbols are valley-filling deposits, closed symbols are veneer deposits, and the gray area indicates the main E-W ridge of the Tugamak Range.

Figure 11: Thicknesses (in $\mathrm{cm}$ ) of Scoria-rich pyroclastic fall deposit. Filled circles are sites where the deposit was found. Solid lines are for well constrained isopachs, dashed lines are less constrained isopachs. The approximate location for the vent is shown (star). Dash-dot lines outline the Tugamak Range and Fisher Caldera.

Figure 12: Thicknesses (upper number, in $\mathrm{cm}$ ) and lithic sizes (lower number when present, in mm) of South Pumice. Filled circles are sites where the deposit was found. Italicized numbers indicate where the deposit is partially to densely welded. 
A dual lobed distribution (dashed lines are approximate isopachs) is suggested by the extent of welding to the south and west. Dash-dot line outlines Fisher Caldera.

Figure 13: Lithic sizes (in mm) of North Pumice (lower number) and Scoria-rich (upper number) fall deposits. Filled circles are sites where lithics were measured. Only lithic sizes for the upper part of the North Pumice are listed. Dash-dot lines outline the Tugamak Range and Fisher Caldera.

Figure 14: Minimum horizontal displacement (curved lines, in fractions of conduit diameter) of a volcanic jet at its fountaining height as a function of mass flux at the vent and wind speed. Solid lines are for a vent $=0.2 \mathrm{~km}$ in diameter, dashed lines are for a vent $=9 \mathrm{~km}$ in diameter. Shown below wind speed is the Saffir-Simpson scale for hurricanes. Mass flux during the Scoria-rich phase of the eruption was at least $10^{7}$ $\mathrm{kg} \mathrm{s}^{-1}$ (dotted line; see text for discussion).

Figure 15: Model for the generation and evolution of Scoria-rich pyroclastic flows. The asymmetric distribution of the pyroclastic flow deposits resulted from erupting through an inclined conduit. Fountaining of the column is thus tilted to the north, whereas the buoyantly rising plume above the vent is blown to the east (out of the page) by upper-level winds. Thick welded deposits with abundant stratification mark the "feeding zone" for the northerly directed pyroclastic flows. As they travel north, the currents interact with the Tugamak Range. The relative density ( $\rho$ ) profile of the segregated density current is shown. See text for discussion.

Figure 16: Reverse modeling of velocities of pyroclastic density currents that deposited the well-sorted ridge deposits in the Tugamak Range. Boxes represent grain-size distributions of the coarsest modes of lithic and scoria. Lines represent $\Sigma_{\mathrm{T}}=1$ for two 
clast densities, where $\Sigma_{\mathrm{T}}$ is the ratio between particle terminal fall velocity and eddy speed. We used $1059 \mathrm{~kg} / \mathrm{m}^{3}$ for scoria density (median value $+1 \sigma$ ) because of their low vesicularity at those sites. Other variables used are dynamic viscosity $\left(1.5 \times 10^{-5}\right.$ Pa s) and kinematic viscosity $\left(3 \times 10^{-5} \mathrm{~m}^{2} \mathrm{~s}^{-1}\right)$ of hot air (assumed to be at $350{ }^{\circ} \mathrm{C}$ ). 
$195^{\circ} 30^{\prime}$

$196^{\circ} 00^{\prime}$

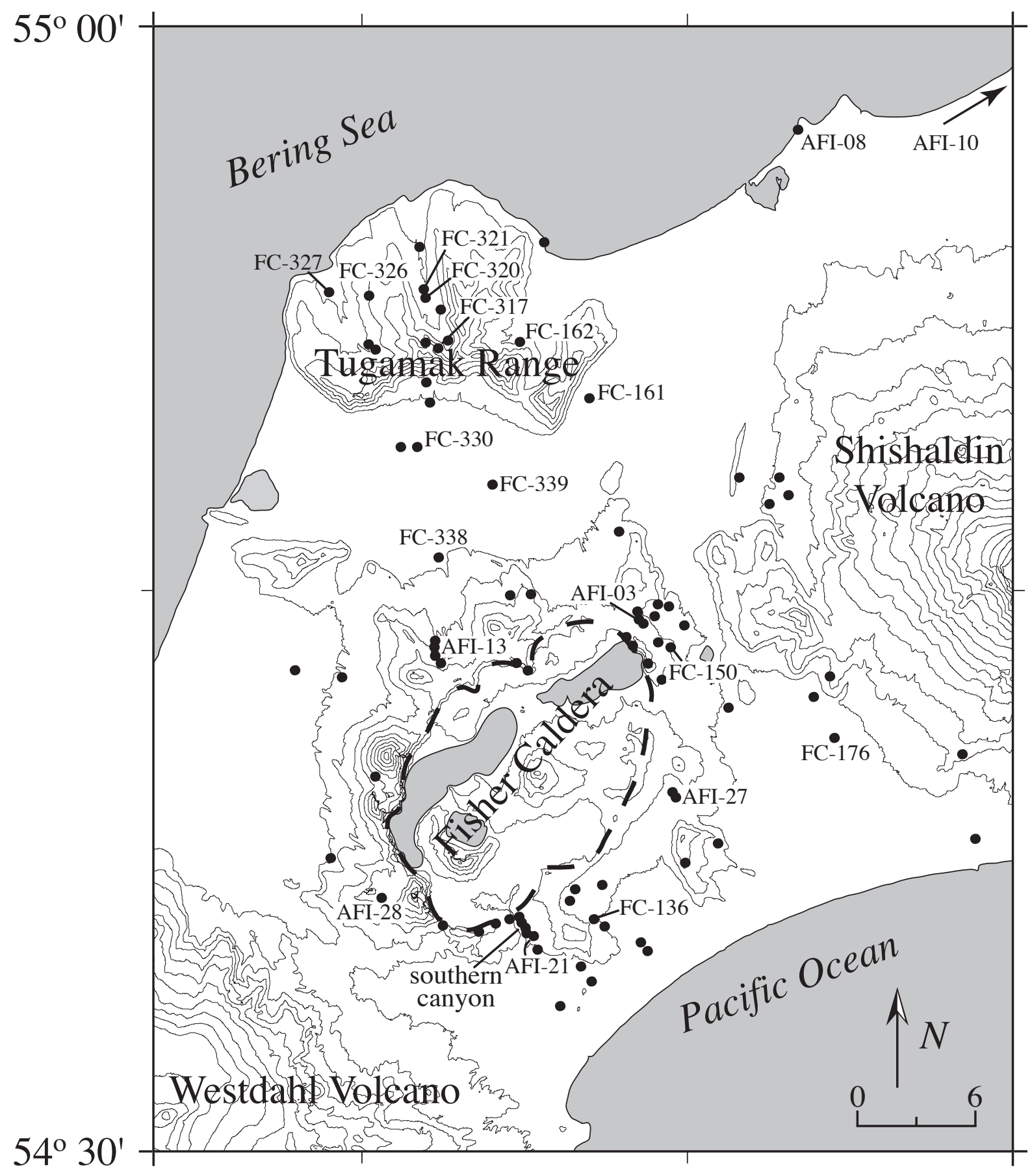

Figure 1 
a.

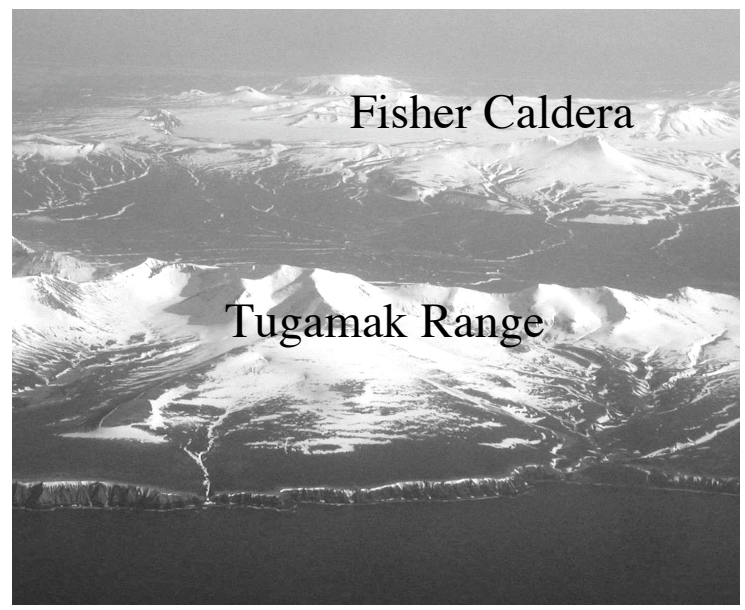

c.

Scoria-rich pyroclastic flow

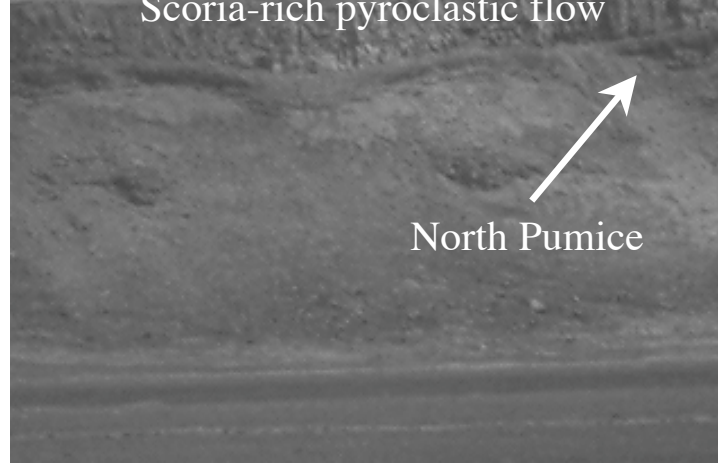

e.

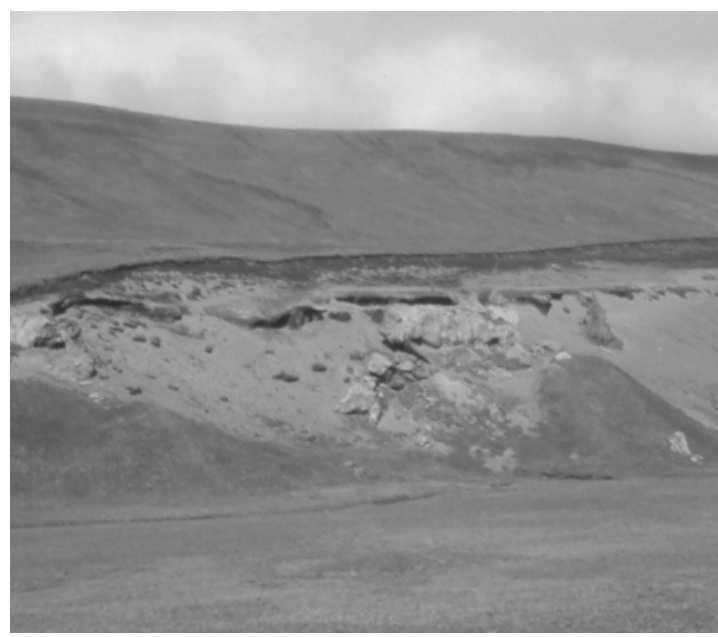

b.

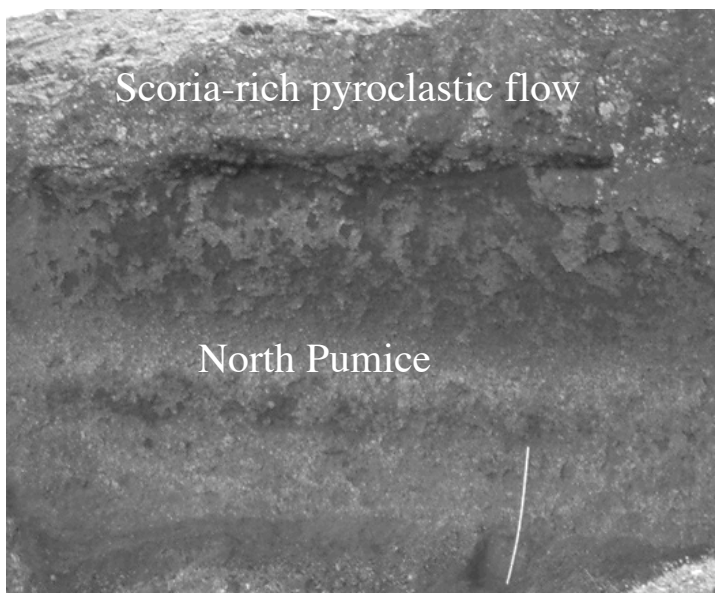

d.

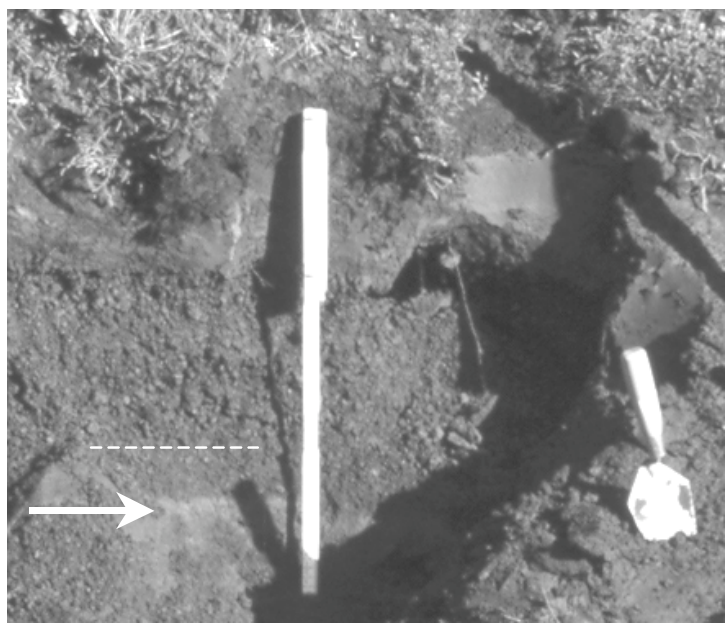

f.

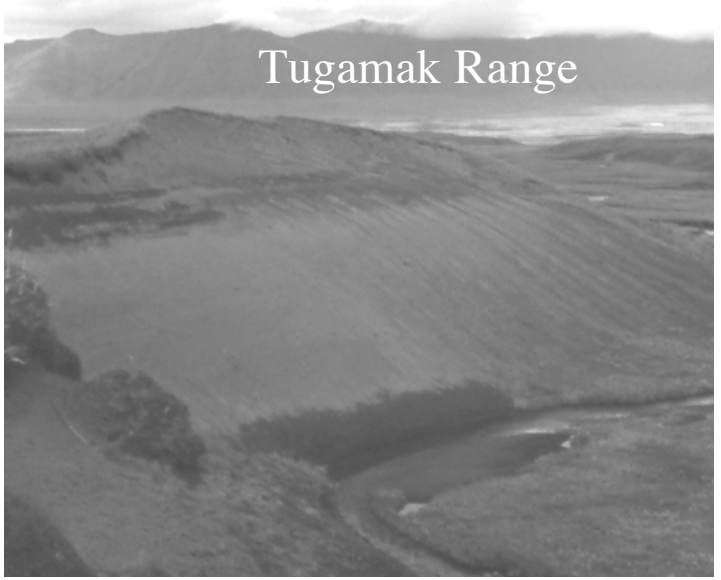

\section{Figure 2}




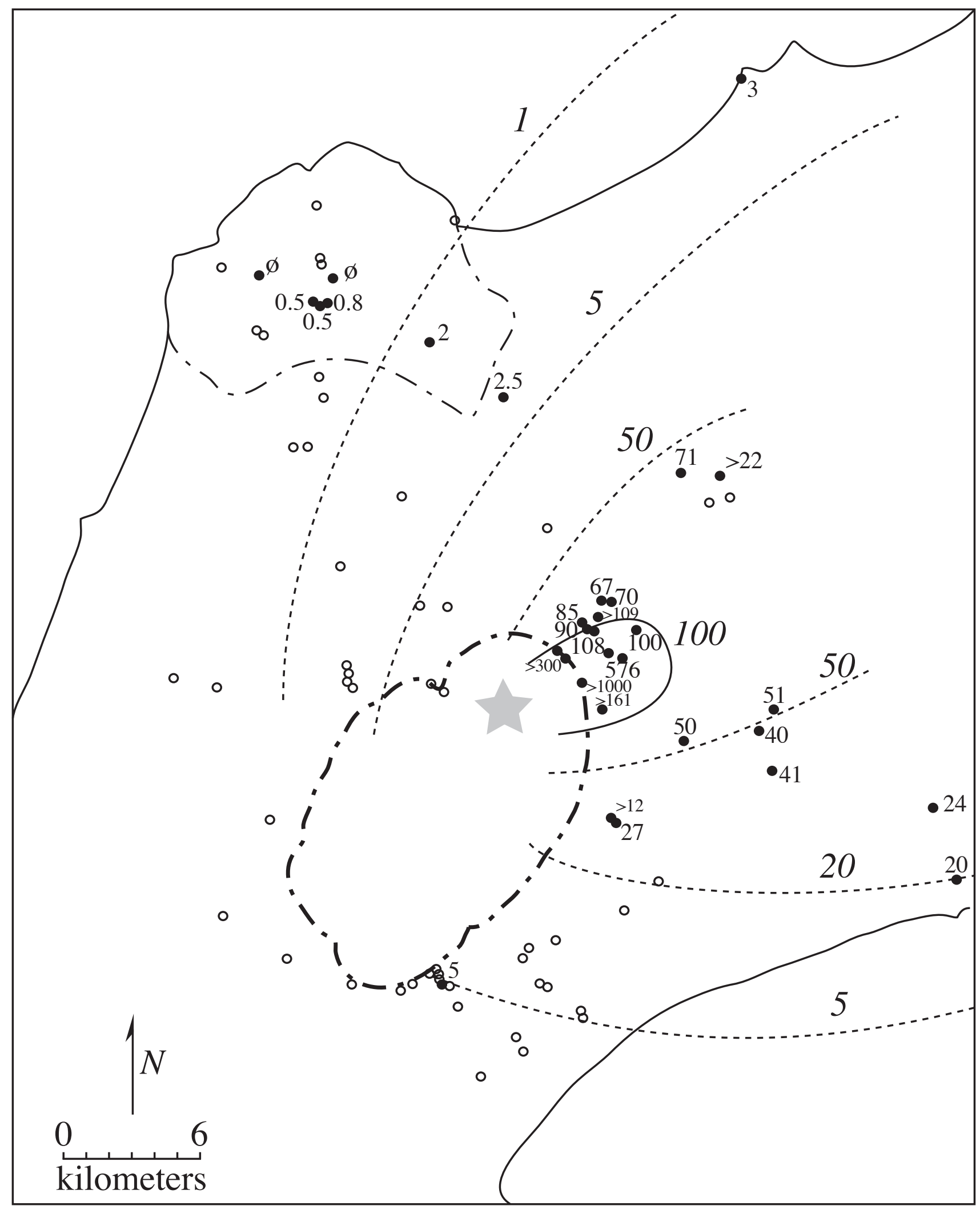

Figure 3 

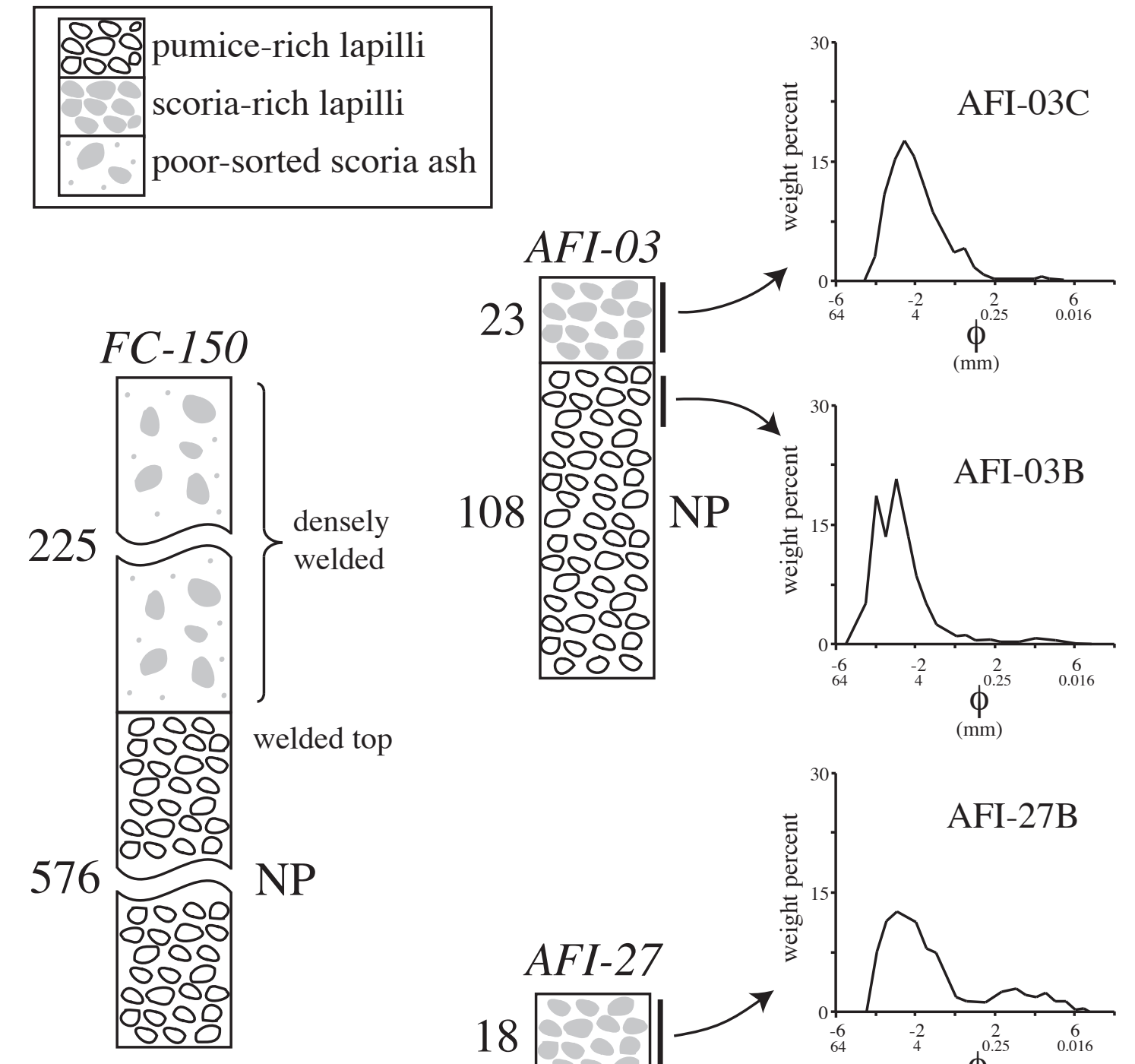

Figure 4
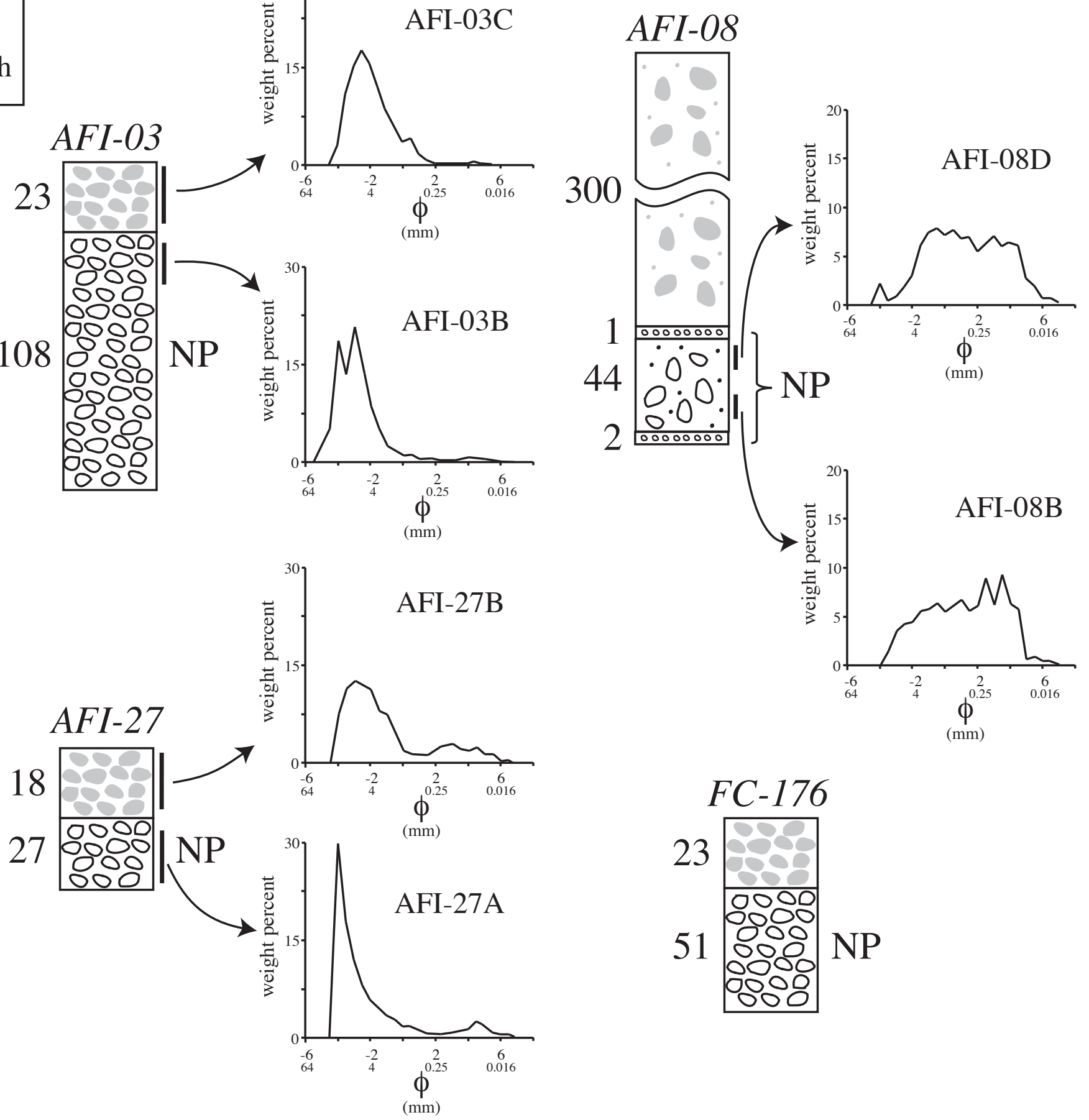

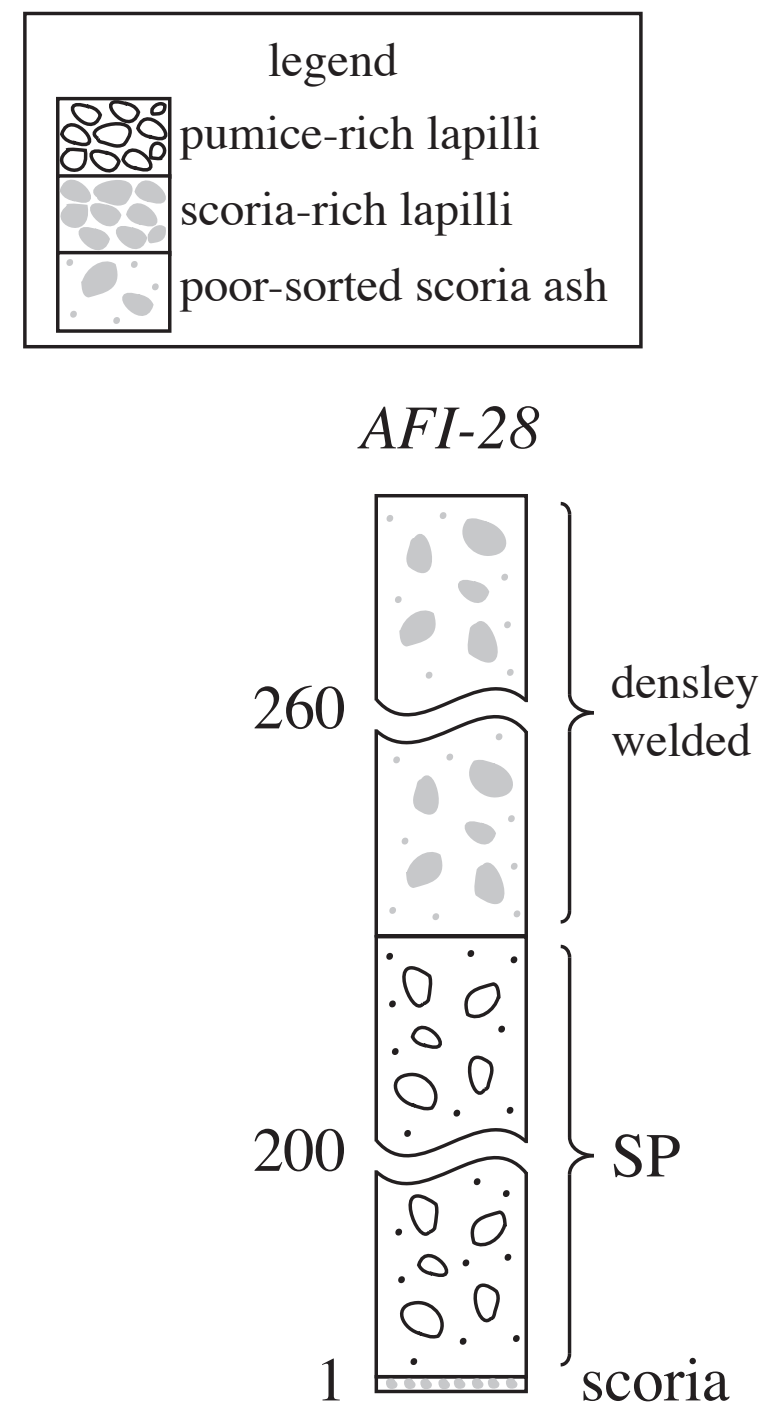

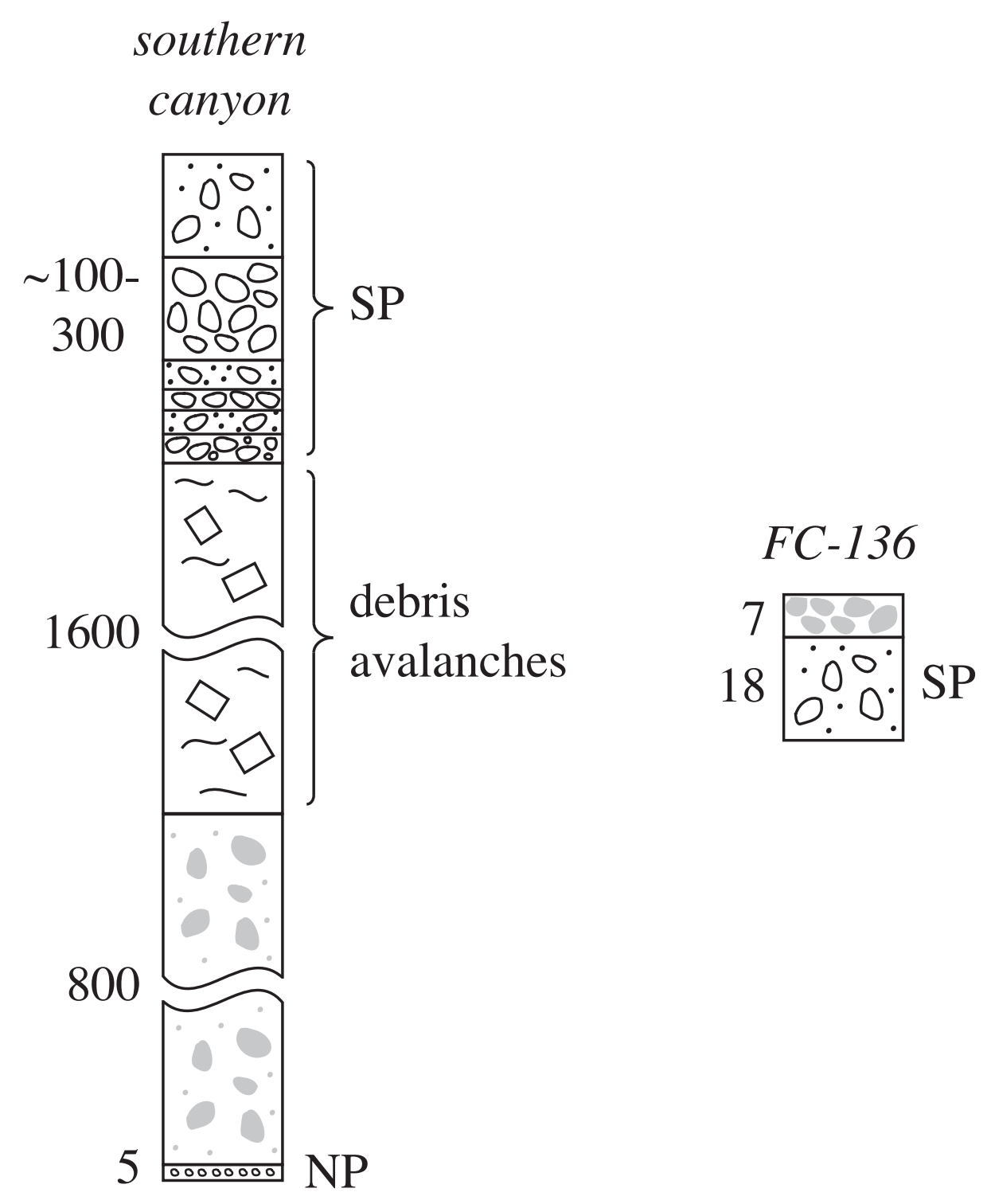

Figure 5 


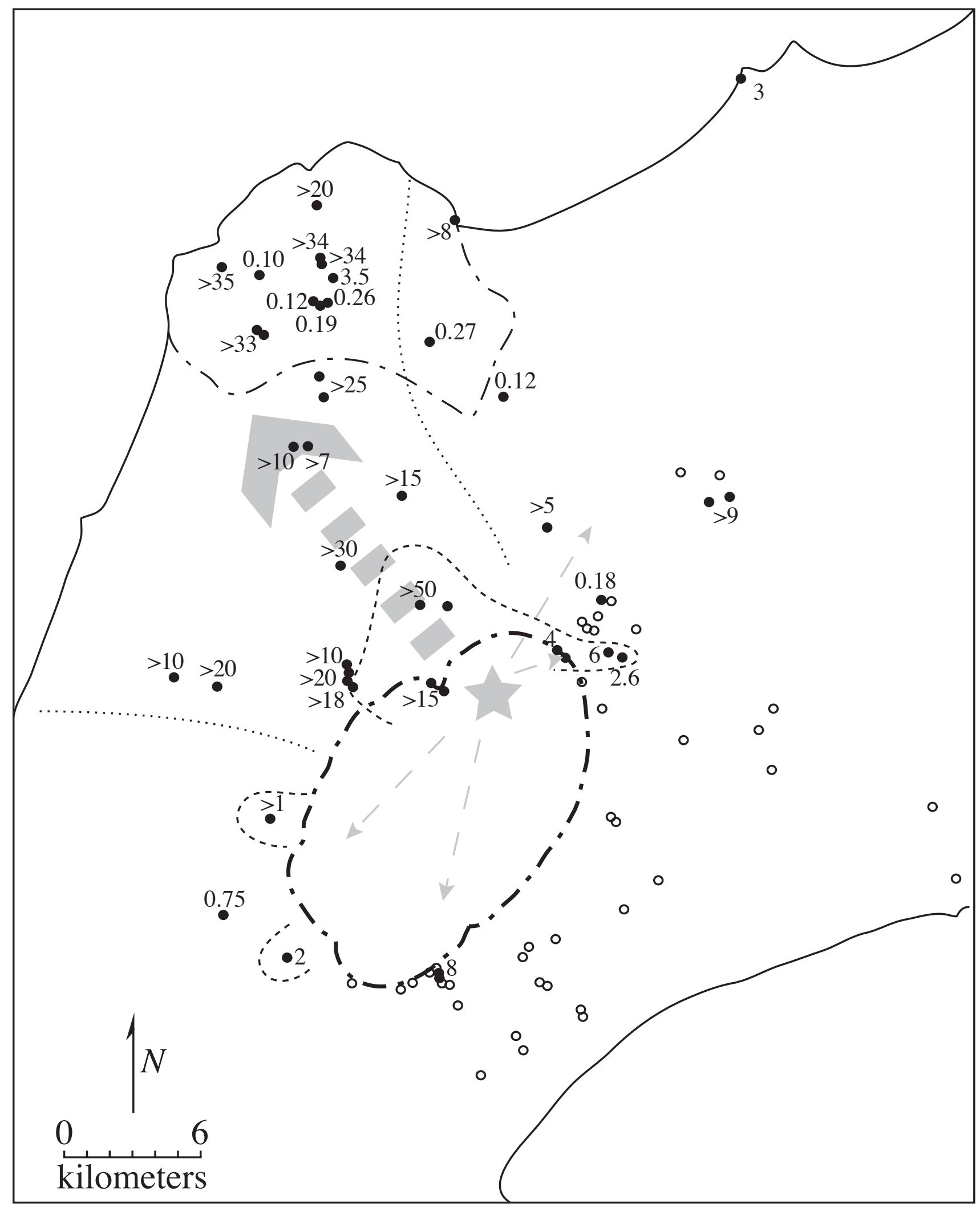

Figure 6 

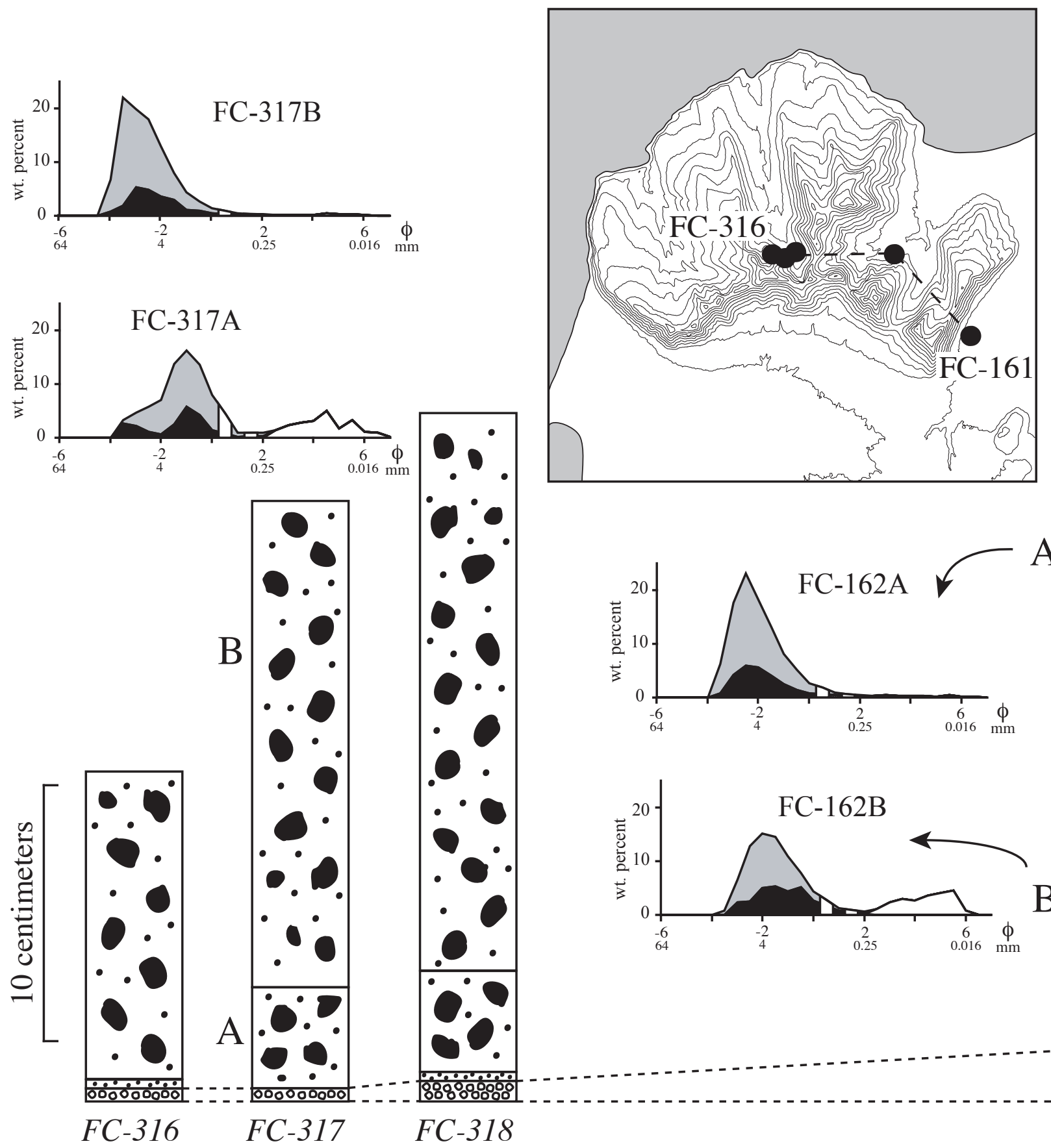

A
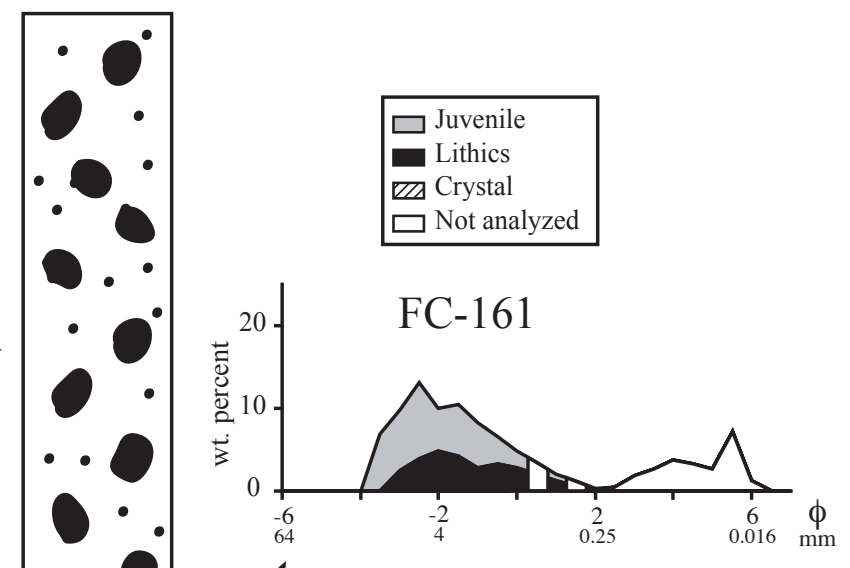

Figure 7 


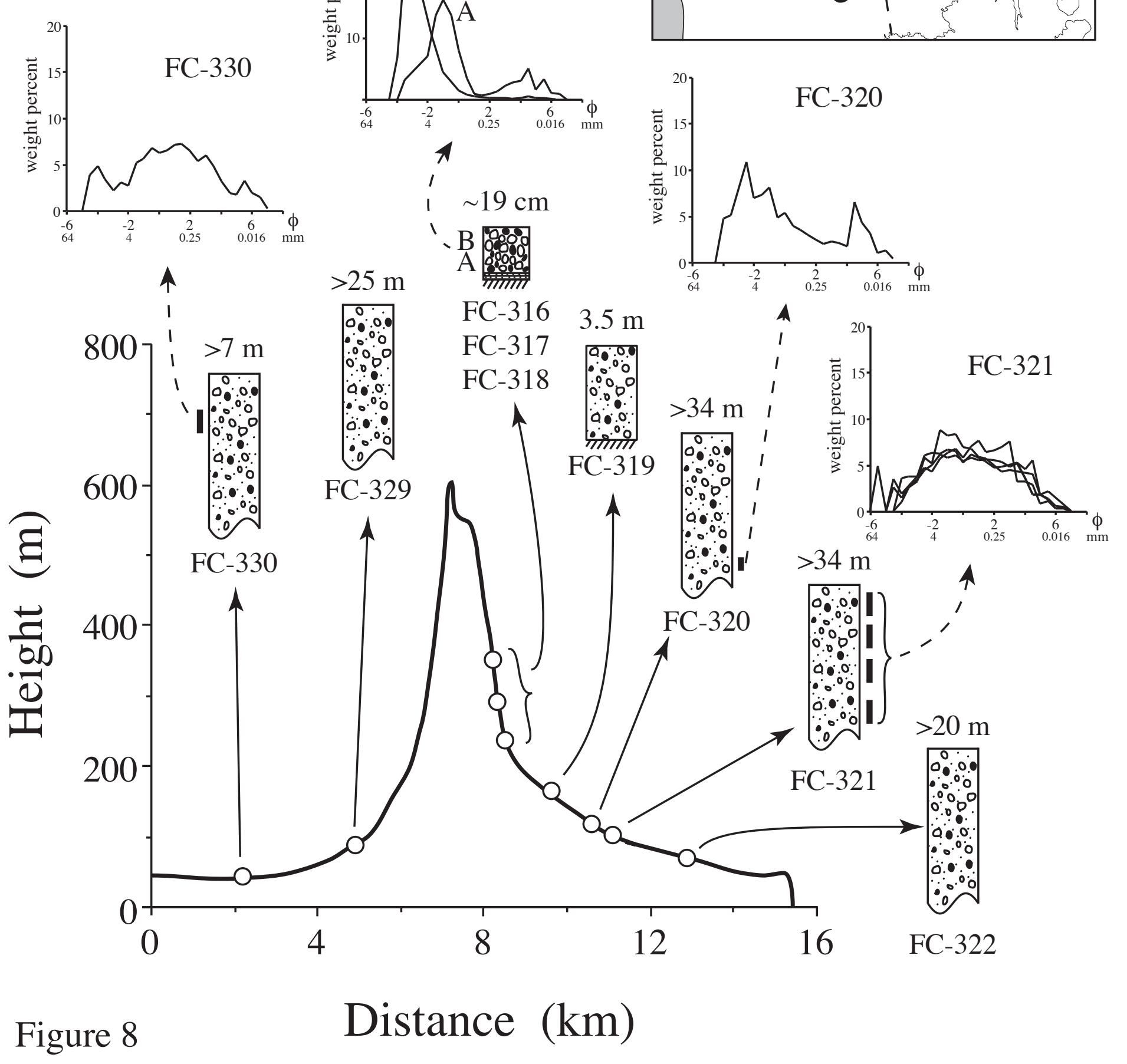




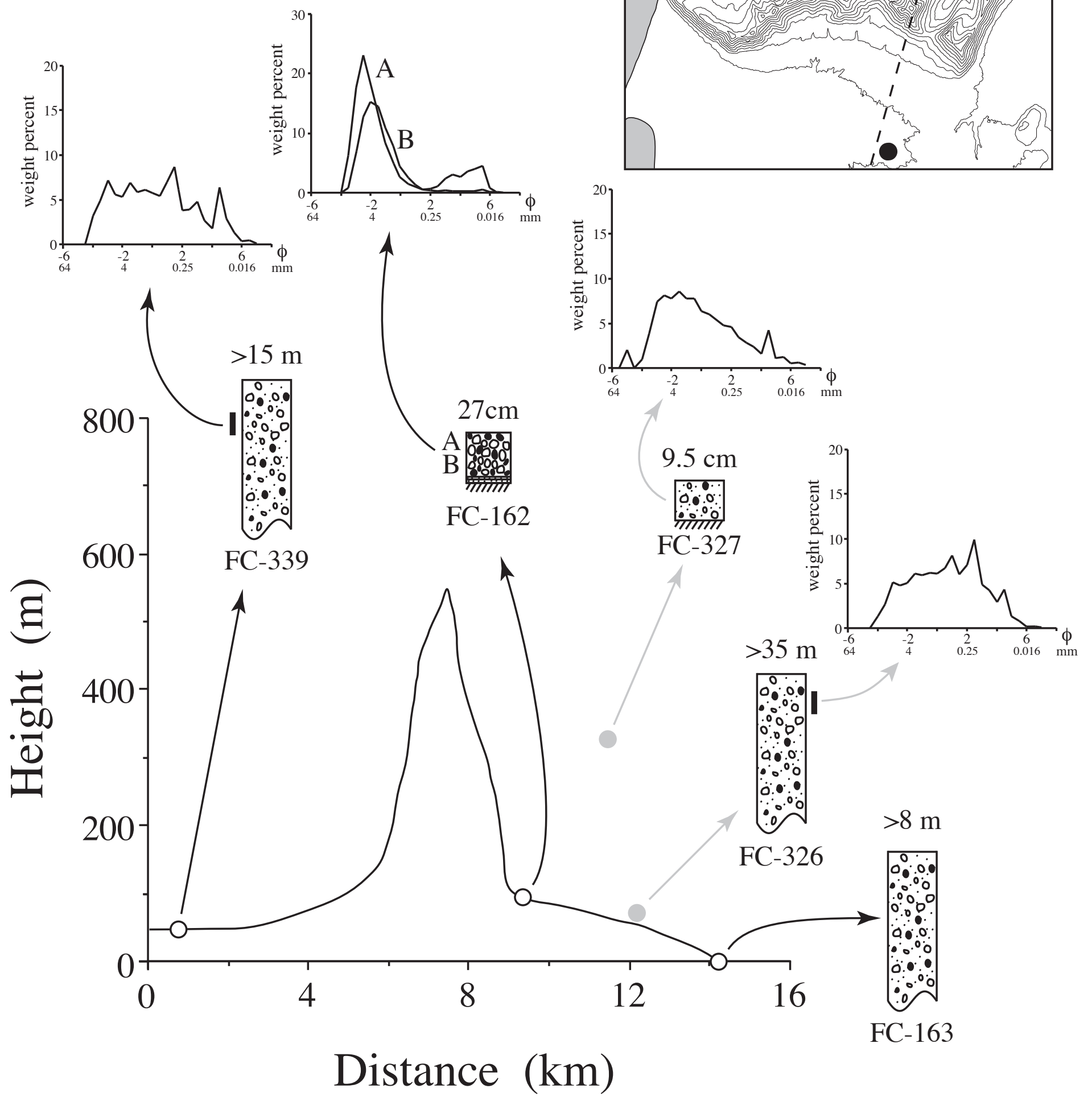

Figure 9 


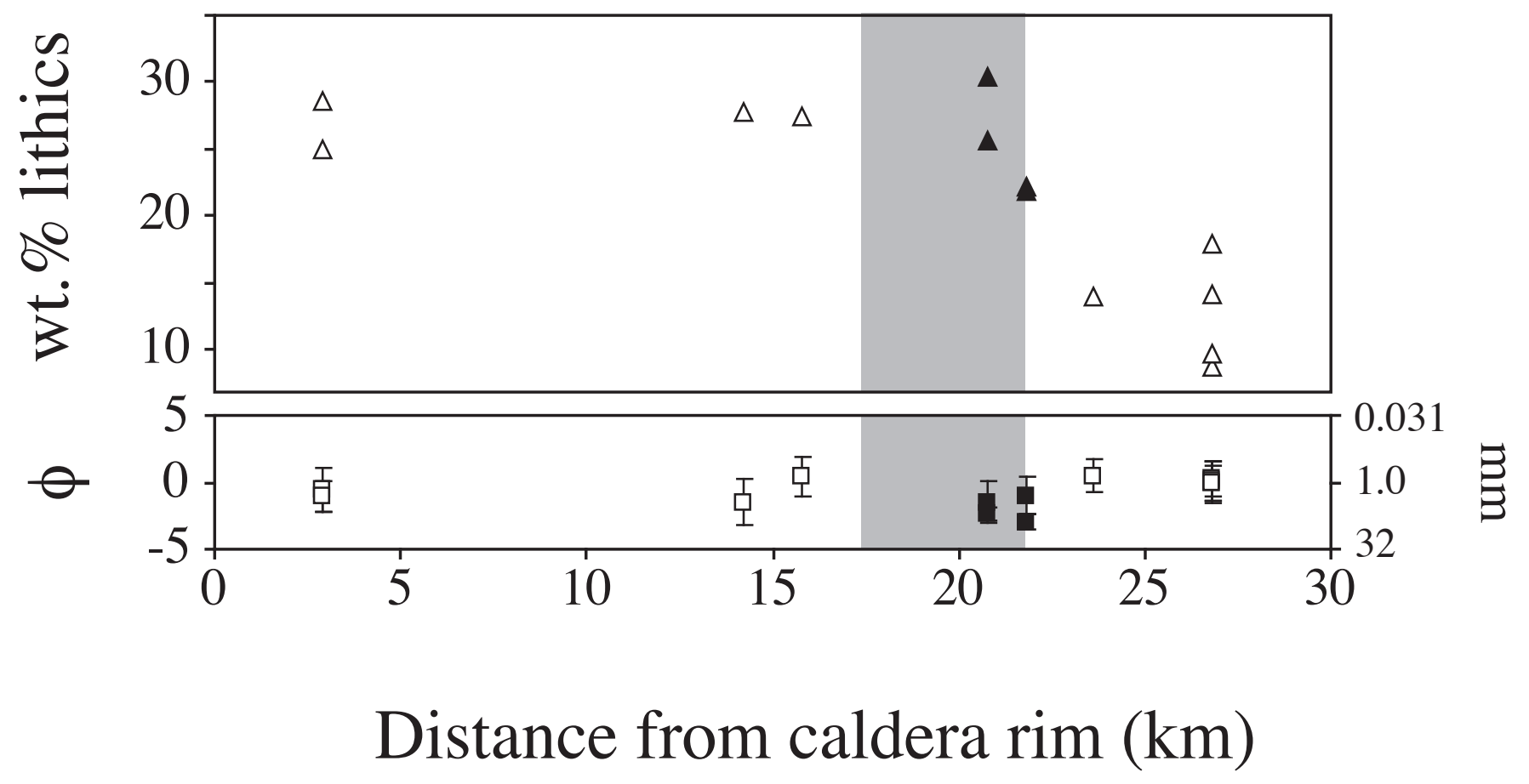

Figure 10 


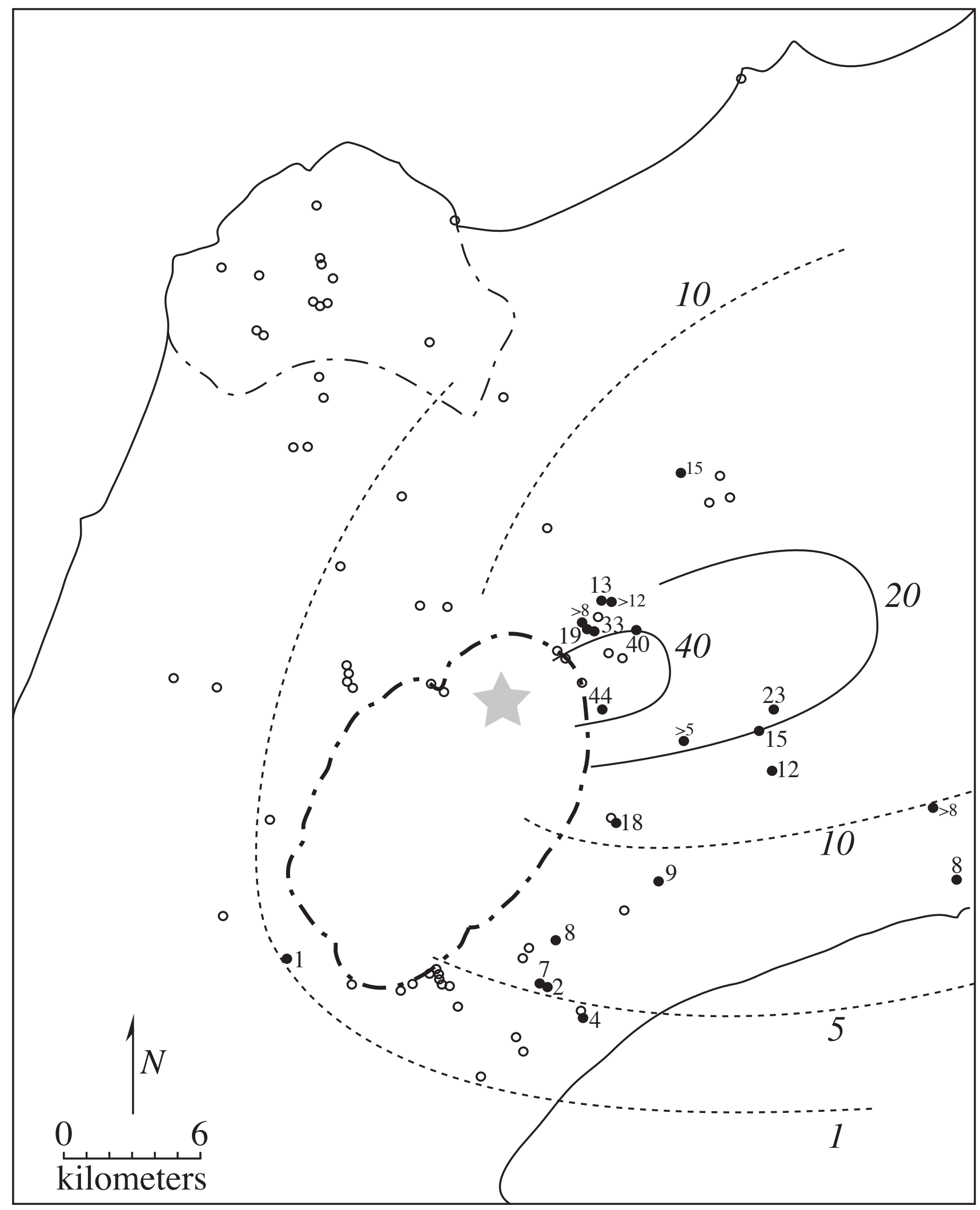

Figure 11 


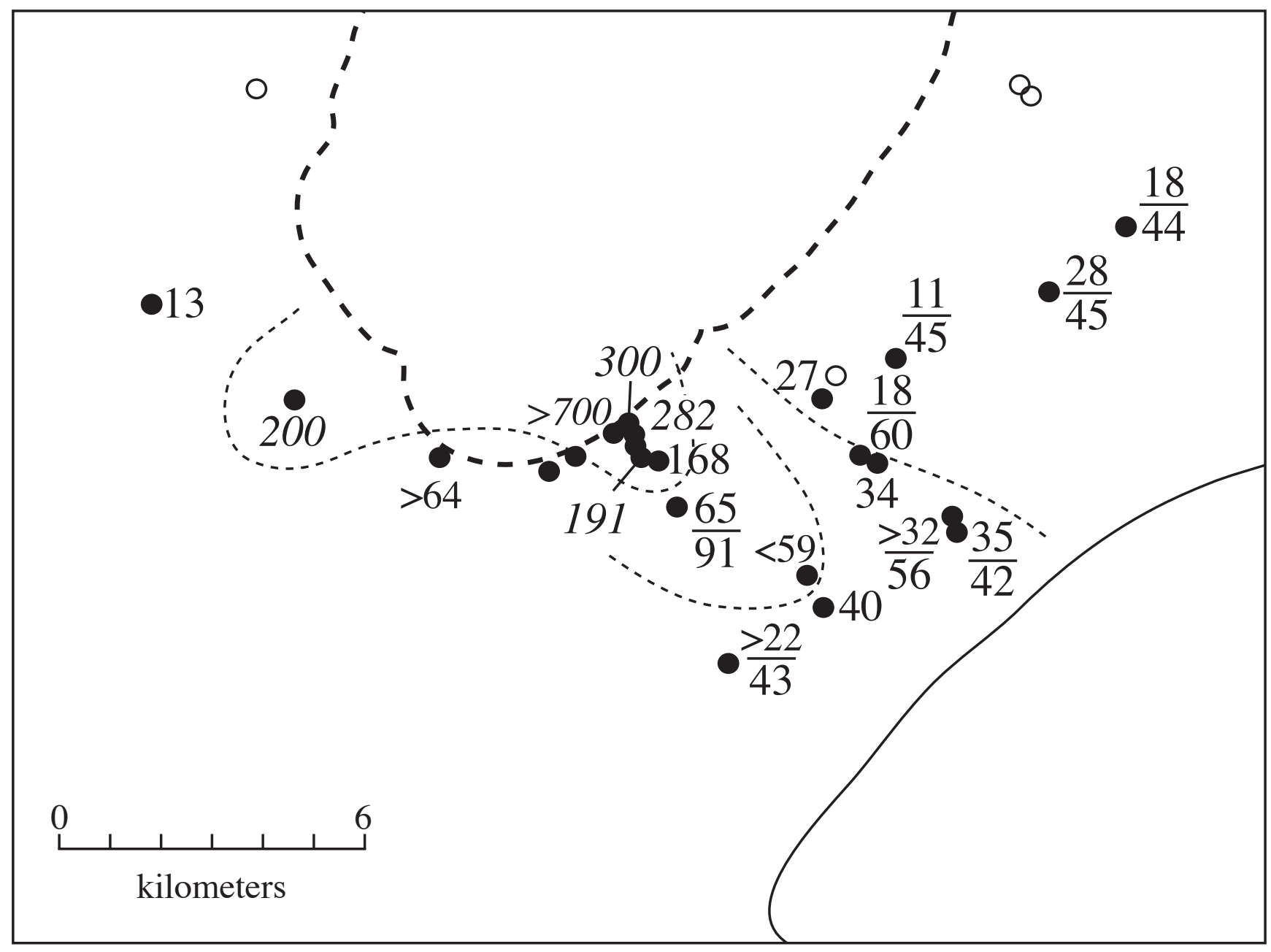

Figure 12 


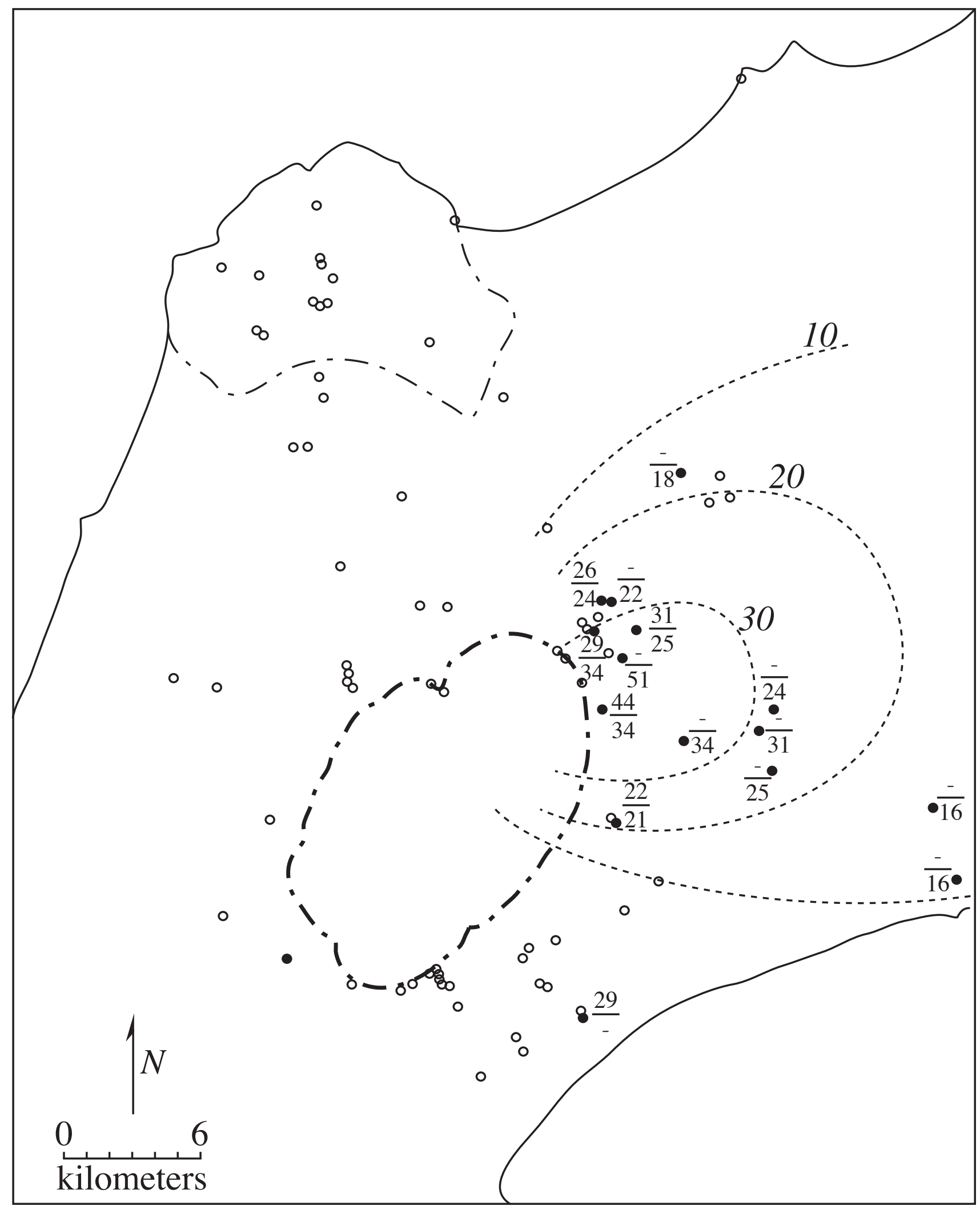

Figure 13 


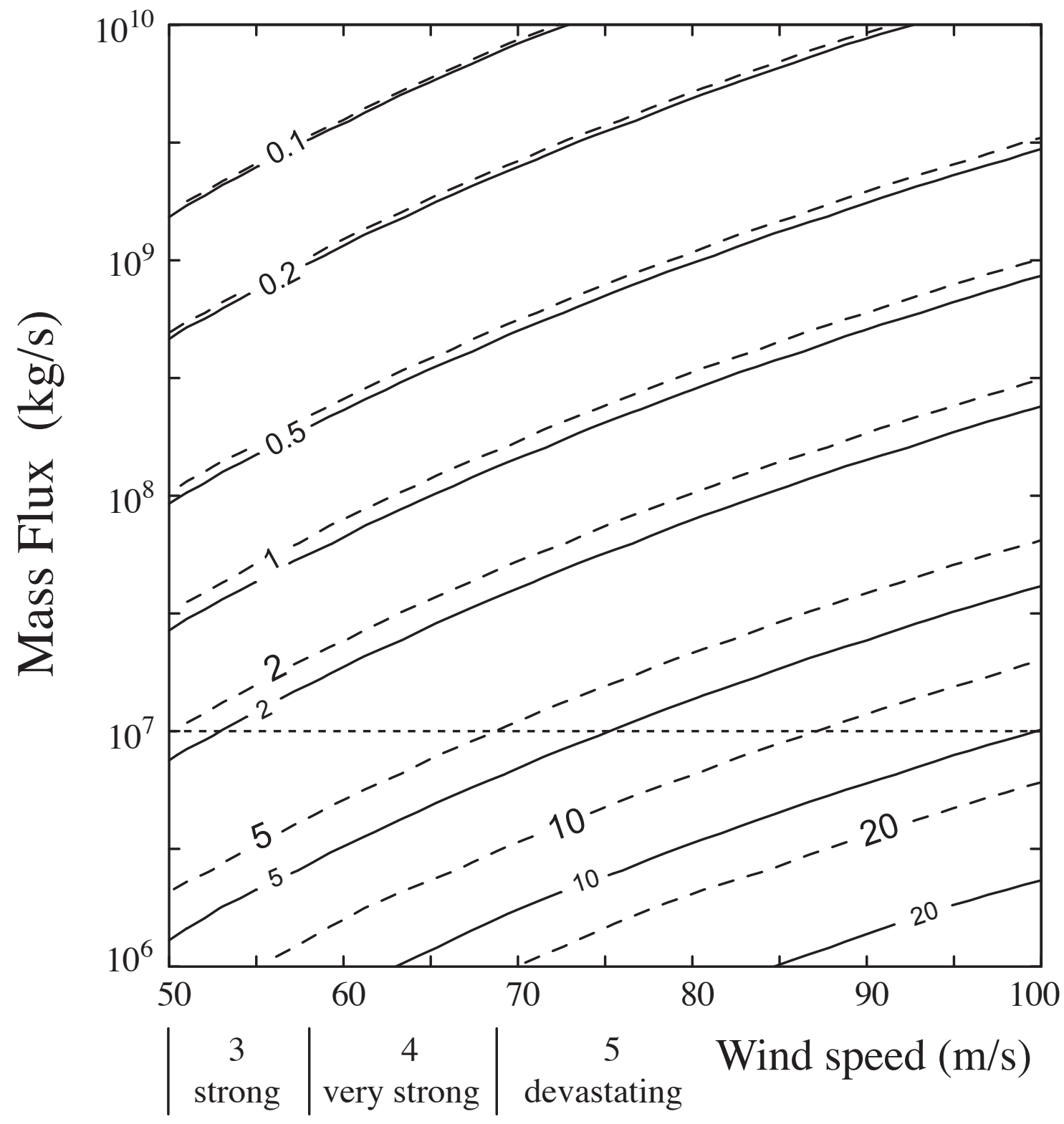

Figure 14 


\section{easterly wind direction}

○

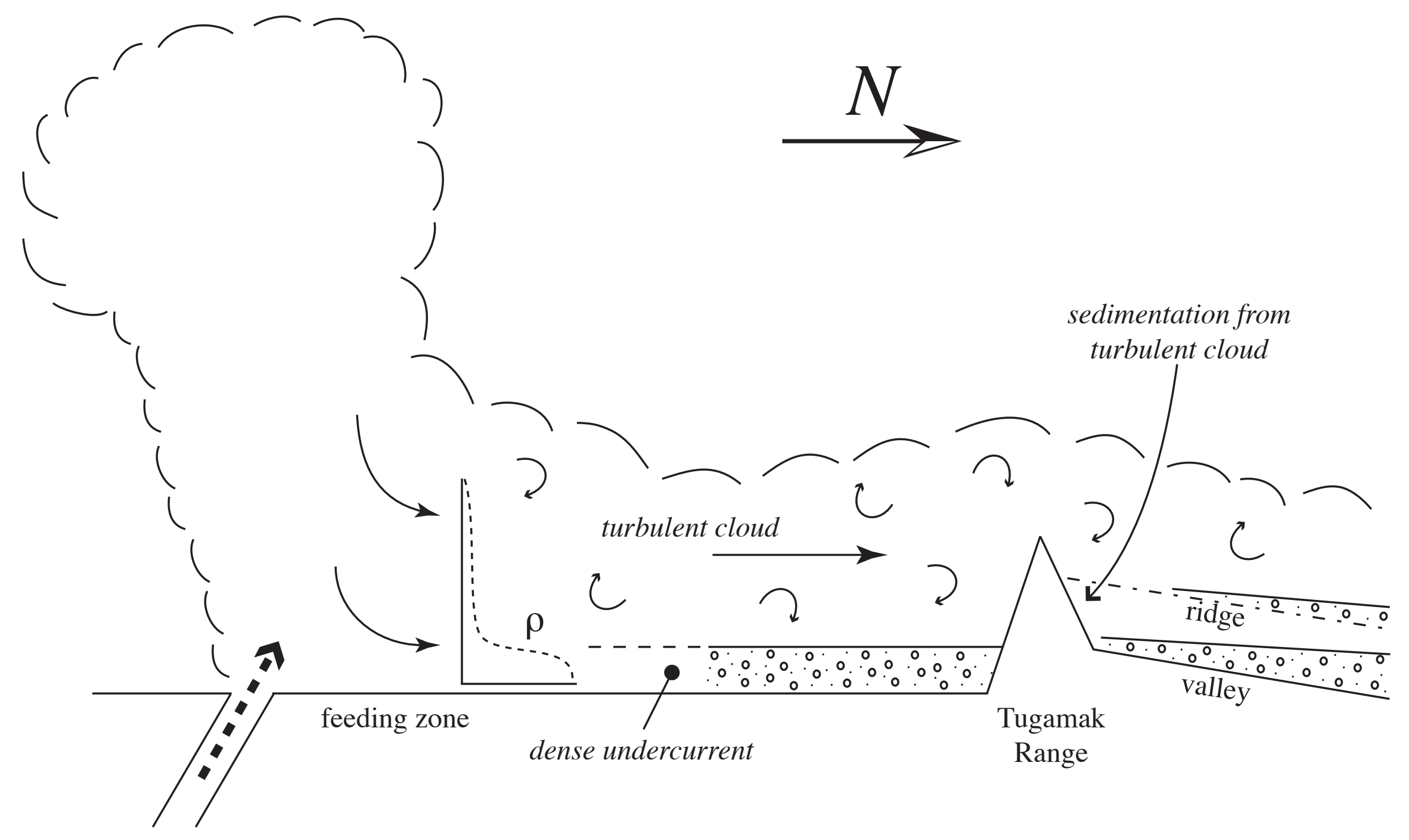

Figure 15 


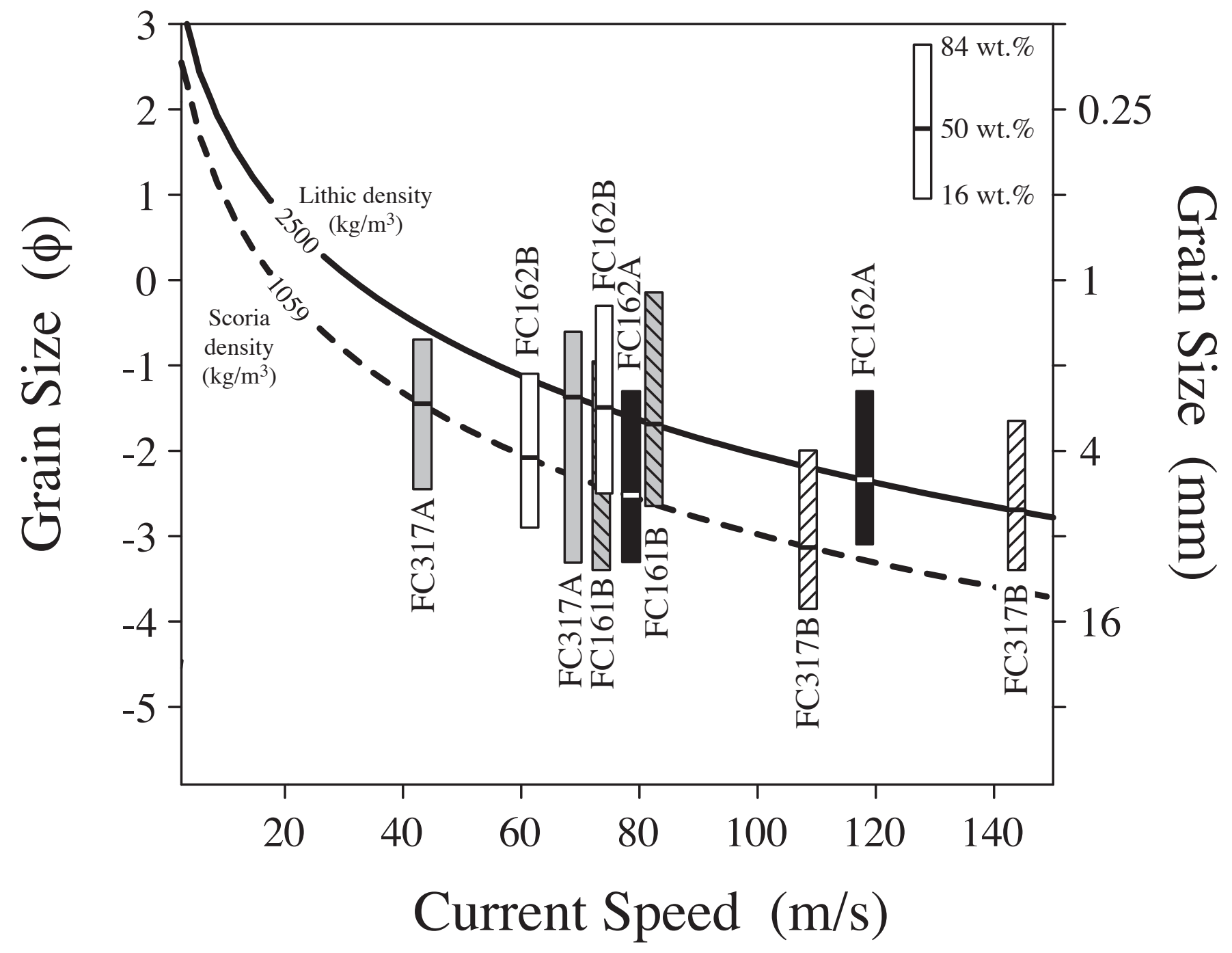

Figure 16 